\begin{tabular}{l|c|c}
\hline ISSN: 0001-5113 & ACTA ADRIAT., & ORIGINAL SCIENTIFIC PAPER \\
AADRAY & 58(1): 3 - 24, 2017 & \\
\hline
\end{tabular}

\title{
Concentrations and origin of polycyclic aromatic hydrocarbons in sediments of the Middle Adriatic Sea
}

\author{
Jelena MANDIĆ ${ }^{1,2^{*}}$ and Maja PAVELA VRANČIĆ ${ }^{3}$
}

\author{
${ }^{1}$ Laboratory of Chemical Oceanography and Sedimentology, \\ Institute of Oceanography and Fisheries, Šetalište I. Meštrovića 63, 21000 Split, Croatia \\ ${ }^{2}$ Unite Biogéochimie et Ecotoxicologie, Laboratoire Biogéochimie des Contaminants \\ Organiques, L'Institut Français de Recherche pour l'Exploitation de la Mer-Centre \\ Atlantique, Rue de l'Ile d'Yeu 21105, 44311 Nantes Cedex 03, France \\ ${ }^{3}$ Department of Chemistry, Faculty of Natural Sciences, Mathematics and Education, \\ University of Split, N. Tesle 12, 21000 Split, Croatia \\ *Corresponding author, e-mail: mandic@izor.hr
}

\begin{abstract}
A total of 208 polycyclic aromatic compounds and their substituted homologues were investigated on eight stations along Croatia-Italy transect in the Middle Adriatic. PAC concentrations were higher in the coastal area than in the open sea area. The highest PAC concentrations were measured in the vicinity of the industrial harbor of Split while the lowest concentrations were observed on stations located in the open sea area. Polycyclic aromatic hydrocarbons were dominant group of compounds on each investigated station with contributions in total PAC concentration of more than $85 \%$. S-PAH concentrations were higher than O-PAH concentration in each sample and tend to decrease as the distance from the coast increased. Contributions of O-PAH in total PAC concentrations were higher in the open sea sediments while S-PAH contributions were higher in the coastal sediment, indicating a different origin of O-PAH. Grain size analysis of the investigated sediments shows the dominance of fine fraction in sediments in the coastal area whereas sandy particles were a dominant fraction in the open sea sediments. TOC concentrations were higher in the open sea area where lower PAH concentrations were observed, indicating a different origin of PAC and TOC. PAH origin was evaluated by application of diagnostic ratios. Pyrogenic origin was determined only on one station whereas dominance of petrogenic PAHs was observed on the most of the stations in the open sea area. Marine traffic was suspected to be the main source of pollution in the open sea area.
\end{abstract}

Key words: polycyclic aromatic compounds, PAH, sediments, diagnostic ratios, marine pollution, Adriatic Sea 


\section{INTRODUCTION}

Polycyclic aromatic hydrocarbons (PAH) are a large group of organic compounds that consist of two or more fused aromatic rings in their structure (VOLHARDT, 1999; EHRENHAUSER, 2015). Along with heterocyclic aromatic compounds, they form a large group of environmental pollutants of which many show potential toxicity to living organisms. PAHs are proved to have disruptive effects on the lymphatic system and hematopoietic activity (ATSDR, 1990b, SANTODONTO et al., 1981). Chronic exposure to PAHs leads to mutagenesis, as they tend to incorporate in DNA structure causing mutagenesis and subsequent cancer formation.

Although some PAH compounds are formed naturally from biological precursors, most of the PAHs in the environment originate from anthropogenic activities such as transportation, power plants, industrial furnaces, coke and black carbon production, asphalt and petroleum cracking (NEFF, 1979). According to the origin, PAHs are commonly divided in natural PAHs, which are released into the environment from a natural source such as biogenesis; and PAHs of anthropogenic origin that are produced in various industrial and urban activities. Anthropogenic PAHs are further divided in petrogenic PAH compounds, produced during the lowtemperature conversion of organic-rich material into the fossil fuel components, and pyrogenic PAHs, produced during the incomplete combustion of organic materials in the various high-temperature process. PAH mixtures emitted from petrogenic sources contain significant amount of alkyl-substituted PAH and PAHs of lower molecular weight, while mixtures emitted from pyrogenic sources are enriched with unsubstituted PAH compounds with more than 3 rings in their structure (GRIMMER et al., 1981; GSCHWEND \& HITES, 1981; GUO et al., 2007; SICRE et al., 1987; BUDZINSKI et al., 1997; YUNKER et al., 2002; TOBISZEWSKI \& NAMIESNIK, 2012).

PAH can enter into marine environment directly, via accidental spillage of petroleum products, or indirectly, by riverine inputs, urban and industrial runoffs, atmospheric deposition etc. Being highly hydrophobic, they tend to adsorb on suspended organic matter and sink through the water column until they finally settle in the bottom sediment (TSAPAKIS et al., 2003; NEFF, 1979). Due to the high persistence toward degradation, PAHs tend to accumulate in sediments in high concentrations persisting toward degradation through long times.

PAHs have been subject of numerous research studies in the last three decades, since the U.S. Environmental Protection Agency (USEPA) included 16 PAH compounds on the list of priority pollutants in the environment, due to their high toxicity for living organisms (USEPA, 1980). High PAH concentrations were reported for the coastal sediments of highly industrialized and urbanized areas such as the big coastal cities and harbors (BENLACHEN et al., 1997; BAUMARD et al., 1998). Considerably lower concentrations were found in the open sea sediments and other remote areas where anthropogenic pressures are minimal or absent.

Many authors have studied PAH concentrations in the sediment of the Adriatic Sea. Values reported for the western Adriatic were in range 31-527 (GUZZELLA \& DE PAOLIS, 1994), corresponding to the values determined in sediments in coastal areas of Chioggia and Ancona (MAGI et al., 2012). Somewhat higher PAH concentrations were reported for the Gulf of Trieste (NOTAR et al., 2001; HEATH et al., 2006) whereas very high PAH concentrations were reported for the Venice lagoon (FATTORE et al., 1997). While these research studies were mainly focused on the northern Adriatic basin and western Adriatic coast, only a few research studies of PAH concentration were conducted in the sediments of the eastern Adriatic Sea. The aim of the present study was to investigate distribution and sources of PAHs in sediment in the middle part of the eastern Adriatic Sea. Presented research provides preliminary results on $\mathrm{PAH}$ concentrations and will serve as a basis for further monitoring and research projects. Except for the PAHs, the list of the target compounds also included heterocyclic aromatic compounds of Sulphur and oxygen, which are commonly emitted with PAHs and can serve as an indicator of PAH origin. In order to find the most reliable indices 
of PAH origin, different diagnostic ratios have been examined and the most probable source of pollution was suggested for the each location.

\section{MATERIAL AND METHODS}

\section{Research area}

PAH concentrations were studied on eight stations situated along the transect Croatia-Italy in the Adriatic Sea, as shown in Fig. 1.

The Adriatic Sea is a semi-enclosed basin connected with the Eastern Mediterranean through Otranto Strait (GRILLI et al., 2013). It is commonly divided into northern, middle and southern Adriatic with the northern part being the shallowest. The middle Adriatic is deeper than the northern, reaching its maximum depth of $270 \mathrm{~m}$ in the Jabuka Pit. Southern Adriatic is the deepest part with the maximum depth of $1250 \mathrm{~m}$. Mean surface circulation consists of cyclonic gyre flowing northward along the eastern side (Eastern Adriatic Current - EAC) and southward return flow along the Western side (Western Adriatic Current) (GRILLI et al., 2013). The Northern Adriatic is highly affected by a large amount of fresh water that is introduced in the Adriatic by the Po River (MARINI et al., 2015). In the northern Adriatic, Dense Water mass (Northern Adriatic Dense Water) is gener- ated during the colder part of the year (autumn and winter), causing a cold bottom current over the Western Adriatic shelf. Transect Croatia (Split) - Italy (Mt. Gargano) is situated in the middle Adriatic, in the vicinity of the borderline between the middle and southern Adriatic. It encompasses the area of the Palagruža Sill and it is influenced by the movement of the Middle Adriatic Dense Water that is generated in Middle Adriatic and resides in the bottom layer of the Jabuka Pit. When a large amount of Middle Adriatic Dense Water is formed, it overflows the Jabuka Pit and joins Northern Adriatic Dense Water that flows toward the southeast (MARINI et al., 2015). Formation and circulation of Northern Adriatic Dense Water and its overflowing of the Jabuka pit influences spreading and distribution of pollutants over the Palagruža Sill and along the Western Adriatic coast (MARINI et al., 2015; GRILLI et al., 2013; VILIBIĆ \& ORLIĆ 2002; ARTEGIANI, 1997).

Research area encompasses three stations ( $\mathrm{S} 1, \mathrm{~S} 2$ and $\mathrm{S} 3$ ) in the coastal area and 5 stations (S4, S5, S6, S7 and S8) located in the open sea area. Station S1 is located in the north-eastern part of Kaštela Bay and is considered an area that is under the great anthropological pressure due to the various industrial and urban activities. The most intensive pressures on this location are from the cement factory, shipyard, industrial

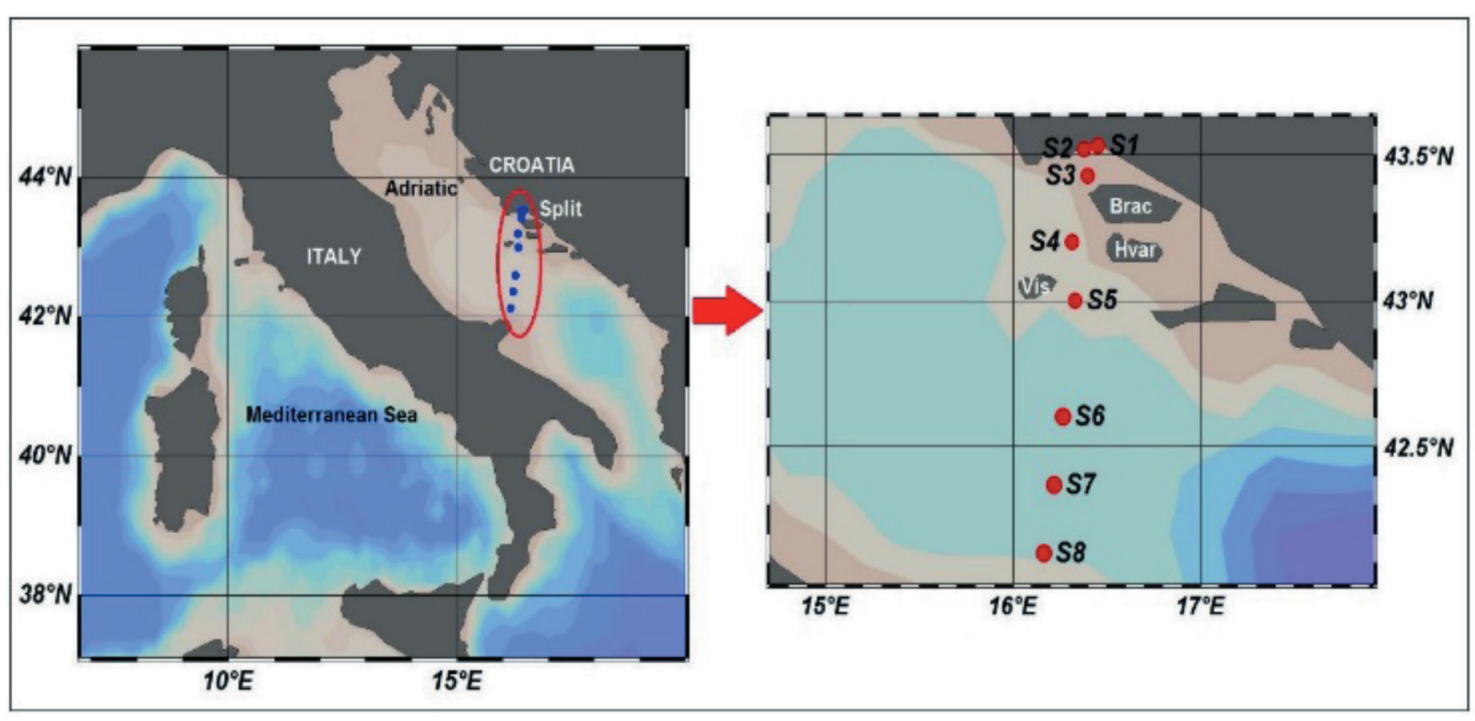

Fig. 1. Sediment sampling locations for determination of polycyclic aromatic compounds 
Table 1. Sampling dates, geographic position and bottom depth at the investigated stations

\begin{tabular}{|c|c|c|c|c|}
\hline STATION & $\begin{array}{c}\text { SAMPLING } \\
\text { DATE }\end{array}$ & $\begin{array}{c}\text { BOTTOM } \\
\text { DEPTH } \\
(\mathbf{m})\end{array}$ & LATITUDE & LONGITUDE \\
\hline $\boldsymbol{S 1}$ & 20.02 .2013 & 18 & $43,5300 \mathrm{~N}$ & $16,4533 \mathrm{E}$ \\
\hline $\boldsymbol{S} \boldsymbol{2}$ & 20.02 .2013 & 38 & $43,5183 \mathrm{~N}$ & $16,3816 \mathrm{E}$ \\
\hline $\boldsymbol{S 3}$ & 18.02 .2013 & 52 & $43,4266 \mathrm{~N}$ & $16,3983 \mathrm{E}$ \\
\hline $\boldsymbol{S} 4$ & 18.02 .2013 & 78 & $43,2000 \mathrm{~N}$ & $16,3166 \mathrm{E}$ \\
\hline $\boldsymbol{S 5}$ & 19.02 .2013 & 105 & $43,0000 \mathrm{~N}$ & $16,3333 \mathrm{E}$ \\
\hline $\boldsymbol{S 6}$ & 18.02 .2013 & 175 & $42,6000 \mathrm{~N}$ & $16,2683 \mathrm{E}$ \\
\hline $\boldsymbol{S 7}$ & 18.02 .2013$. & 102 & $42,3666 \mathrm{~N}$ & $16,2200 \mathrm{E}$ \\
\hline $\boldsymbol{S} \boldsymbol{}$ & 18.02 .2013 & 116 & $42,1333 \mathrm{~N}$ & $16,1666 \mathrm{E}$ \\
\hline
\end{tabular}

port and urban activities from the nearby cities. Station 2 is located in the middle of the bay and it is affected by anthropogenic activities. Inputs of freshwater by the Jadro River, in the northeastern part of the bay, are responsible for the lower salinity in the bay if compared to the open sea sediments (ANĐELIĆ et al., 2015). Station S3 is located in the coastal area of Split, between the islands Brač and Šolta. Stations S4, S5, S6 and $\mathrm{S} 7$ are the most distant from both eastern and western Adriatic coast, thus anthropogenic pressures are the least expressed. Marine transportation was recognized as the most important activity in this area. Station S8 is approximately 20 miles away from the western Adriatic coast and is also affected by marine transportation. Formation and circulation of Northern and Middle Adriatic Dense Waters contribute to pollution state in this area, bringing additional pollutants that are introduced in the Adriatic by the Po River (GRILLI et al., 2013; MARINI et al., 2015). Additional information for each location is given in Table 1.

Sediment samples were taken from the research vessel "BIOS DVA" during the campaign in February 2013. Approximately 100 grams of the top sediment layer was obtained from each station by the means of a grab sampler. Samples were wrapped in pre-cleaned aluminum foil and subsequently stored at the temperature of $-20{ }^{\circ} \mathrm{C}$. Frozen samples were transferred to a laboratory and lyophilised. Dry sediment samples were sieved through $0,2 \mathrm{~mm}$ screen and transferred to IFREMER laboratories where overall analyses were done. In order to minimize contamination, during the whole procedure, plastic was strictly forbidden and all used laboratory equipment was thoroughly cleaned and heated on $4500^{\circ} \mathrm{C}$ before use.

\section{PAC analyses}

Polycyclic aromatic compounds were determined according to the method developed by IFREMER laboratories (TRONCZYNSKI et al., 2004). Ten grams of each sediment sample was weighed directly into the extraction cell and spiked with $150 \mu \mathrm{l}$ of an internal standard solution containing two deuterated PAH compounds (Phenanthrene- $\mathrm{d}_{10}$ and Benzo[e]pyrene- $\mathrm{d}_{12}$ ). Extraction was performed in ASE (Accelerated solvent extractor) with dichloromethane (DCM) as a solvent under $100^{\circ} \mathrm{C}$ and 138 Bar. Each sample was washed 5 times with DCM for two minutes. Sediment extracts were collected in two separate containers and joined upon the extraction. Samples were evaporated in a rotary evaporator and further concentrated under gentle nitrogen steam up to the volume of $1 \mathrm{ml}$. Concentrated extracts were spiked with small portions of isooctane and additionally evaporated until the final volume of $0,5 \mathrm{ml}$ was reached.

Column chromatography with $\mathrm{SiO}_{2}$ and $\mathrm{Al}_{2} \mathrm{O}_{3}$ as sorbents was employed for cleaning and fractionation. In order to control the cleaning process, $300 \mu \mathrm{L}$ of standard solution was added in a separate column and afterward treated as the samples extracts. After addition of the samples, columns were washed with $36 \mathrm{ml}$ of hexane for F1 fraction; $30 \mathrm{ml}$ of hexane/DCM 
mixture containing $10 \%$ of DCM for F2 and 20 $\mathrm{ml}$ of hexane/DCM containing $25 \%$ of DCM for F3 fraction. These three fractions were collected in the same flask, evaporated in the rotary evaporator and concentrated under nitrogen steam. Upon the concentration, residues were dissolved in isooctane up to the volume of 0,5 $\mathrm{mL}$. Elementary sulphur was removed by addition of activated copper.

Sediment extracts were analyzed with an Agilent 6890 gas chromatograph (GC) using DB-5 MS capillary column (60 m long, $0,25 \mathrm{~mm}$ of internal diameter, phase thickness of $0,25 \mu \mathrm{m}$ ) in On column injection mode.

$1 \mu \mathrm{L}$ of sample was injected with COMBIPAL CTC autosampler. The oven was programmed as follows: holding on $50^{\circ} \mathrm{C}$ for 1 minute, from $50^{\circ} \mathrm{C}$ to $100^{\circ} \mathrm{C}$ at $15^{\circ} \mathrm{C} / \mathrm{min}$, from $100^{\circ} \mathrm{C}$ to $300^{\circ} \mathrm{C}$ at $4^{\circ} \mathrm{C} / \mathrm{min}$, holding at $300^{\circ} \mathrm{C}$ for 20 minutes. Helium with a flow rate of 0,8 $\mathrm{ml} / \mathrm{min}$ was used as a carrier gas.

Identification of compounds was done with an Agilent $5973 \mathrm{~N}$ mass spectrometer operating in EI mode $\left(70 \mathrm{Ev}, \mathrm{T}=230^{\circ} \mathrm{C}\right)$ by the acquisition of the total mass spectra from 40-400 AMU and total ionic current (TIC) and additionally verified according to GC retention times. Quantitative analysis was done in selected ion monitoring (SIM) mode in relation to predeuterated compounds (Acenaphthalene- $\mathrm{d}_{10}$, Fluorene- $\mathrm{d}_{10}$, Pyrene- $\mathrm{d}_{10}$, Benzo[a]anthracene- $\mathrm{d}_{12}$ and Indeno $[1,2,3-c d]$ pyrene- $\left.\mathrm{d}_{12}\right)$ added to the samples by an auto-sampler prior injection. Set of ten standard solutions with parent compounds concentration ranging from 0,005 to $8 \mathrm{ng} \mu \mathrm{L}^{-1}$ were used for calibration. A separate calibration curve was used for very low concentrations of PAHs in extracts $\left(0,005-0,250 n g \mu^{-1}\right)$.

QA/QC procedure followed an internal protocol developed by IFREMER laboratories. Laboratory and field blanks were analyzed along with each batch of sediment samples. Overall, the analytical protocol was controlled by use of a surrogate standard solution containing phenanthrene- $\mathrm{d}_{10}$ and benzo[e]pyrene- $\mathrm{d}_{12}$ added to each sample before extraction, which enable to verify losses of analytes of interests during the entire procedure. Samples with recoveries below $70 \%$ were rejected and reanalyzed.

Standard reference materials (SRM 1491 and SRM 2977) from the National Institute of Standards and Technology-NIST were incorporated within a batch of sediment samples. The method detection limits were individually calculated for each sample. Laboratory proficiency for PAH analysis is also evaluated through regular participation in the QUASIMEME (Quality assurance of Information for Marine Environmental Monitoring in Europe) exercises. List of target polycyclic aromatic compounds, abbreviations and internal standards used for quantification are shown in Table 2.

Table 2. List of parent and alkyl-substituted PAHs, sulphur heterocyclic aromatic compounds and oxygen heterocyclic aromatic compounds determined in sediment samples; abbreviation, molecular weight and internal standard used as a reference

\begin{tabular}{|l|l|c|c|}
\hline COMPOUND NAME & ABBREVATION & MW & INTERNAL STANDARD \\
\hline PAHs and alkylated homologues & Na & 128 & Acenaphtene- $d_{10}$ \\
\hline Naphtalene & C1-N & 142 & Acenaphtene- $d_{10}$ \\
\hline C1-Naphtalenes & C2-N & 156 & Acenaphtene- $d_{10}$ \\
\hline C2-Naphtalenes & C3-N & 170 & Acenaphtene- $d_{10}$ \\
\hline C3-Naphtalenes & C4-N & 184 & Acenaphtene- $d_{10}$ \\
\hline C4-Naphtalenes & ACE & 152 & Acenaphtene- $d_{10}$ \\
\hline Acenaphtene & ACY & 154 & Acenaphtene- $d_{10}$ \\
\hline Acenaphtylene & F & 166 & Fluorene- $_{10}$ \\
\hline Fluorene & C1-F & 180 & Fluorene- $_{10}$ \\
\hline C1-Fluorenes &
\end{tabular}


(Cont'd Table 2)

\begin{tabular}{|c|c|c|c|}
\hline C2-Fluorenes & $\mathrm{C} 2-\mathrm{F}$ & 194 & Fluorene- $\mathrm{d}_{10}$ \\
\hline Anhtracene & ANT & 178 & Fluorene- $\mathrm{d}_{10}$ \\
\hline Phenanthrene & PHE & 178 & Fluorene- $\mathrm{d}_{10}$ \\
\hline C1-Phenanthrene & C1-PHE & 192 & Fluorene- $\mathrm{d}_{10}$ \\
\hline C2- Phenanthrene & C2-PHE & 206 & Fluorene- $\mathrm{d}_{10}$ \\
\hline C3- Phenanthrene & C3-PHE & 220 & Fluorene- $\mathrm{d}_{10}$ \\
\hline Fluoranthene & FLA & 202 & Pyrene- $\mathrm{d}_{10}$ \\
\hline Pyrene & PY & 202 & Pyrene- $\mathrm{d}_{10}$ \\
\hline C1-Pyrenes & C1-PY & 216 & Pyrene- $\mathrm{d}_{10}$ \\
\hline C2-Pyrenes & C2-PY & 230 & Pyrene- $\mathrm{d}_{10}$ \\
\hline Retene & RET & 219 & Pyrene- $\mathrm{d}_{10}$ \\
\hline Perylene & PER & 252 & Benzo $[a]$ anthracene- $\mathrm{d}_{12}$ \\
\hline Benzo[a]anthracene & $\mathrm{BaA}$ & 228 & Benzo $[a]$ anthracene- $\mathrm{d}_{12}$ \\
\hline Chrysene & CHR & 228 & Benzo $[a]$ anthracene- $\mathrm{d}_{12}$ \\
\hline C1-Chrysene & C1-CHR & 242 & Benzo $[a]$ anthracene- $\mathrm{d}_{12}$ \\
\hline C2-Chrysene & C2-CHR & 256 & Benzo $[a]$ anthracene- $\mathrm{d}_{12}$ \\
\hline C3-Chrysene & C3-CHR & 270 & Benzo $[a]$ anthracene- $\mathrm{d}_{12}$ \\
\hline Benzo $[a]$ pyrene & $\mathrm{BaP}$ & 252 & Benzo[a]anthracene- $\mathrm{d}_{12}$ \\
\hline Benzo[e]pyrene & $\mathrm{BeP}$ & 252 & Benzo[a]anthracene- $\mathrm{d}_{12}$ \\
\hline Dibenzo[a,e]pyrene & DBP & 302 & Benzo[a]anthracene- $\mathrm{d}_{12}$ \\
\hline Benzo $[b+j+k]$ fluoranthene & BFL & 252 & Benzo $[a]$ anthracene- $\mathrm{d}_{12}$ \\
\hline C1-Benzofluoranthenes & C1-BFL & 266 & Benzo[a]anthracene- $\mathrm{d}_{12}$ \\
\hline Naphto[1,2-k]fluoranthene & NaphtoFL & 302 & Indeno $[1,2,3-c d]$ pyren- $\mathrm{d}_{10}$ \\
\hline Benzo[ghi]perylene & BPER & 276 & Indeno $[1,2,3-c d]$ pyren- $\mathrm{d}_{10}$ \\
\hline Dibenzo $[a, h]$ anthracene & DBA & 278 & Indeno $[1,2,3-c d]$ pyren- $\mathrm{d}_{10}$ \\
\hline Indeno $[1,2,3-c d]$ pyrene & IP & 276 & Indeno $[1,2,3-c d]$ pyren- $\mathrm{d}_{10}$ \\
\hline Coronene & COR & 300 & Indeno $[1,2,3-c d]$ pyren- $\mathrm{d}_{10}$ \\
\hline C-302 & C-302 & 302 & Indeno $[1,2,3-c d]$ pyren- $\mathrm{d}_{10}$ \\
\hline \multicolumn{4}{|l|}{ S-PAH and alkylated homologues } \\
\hline Dibenzothiophenes & DBT & 184 & Fluorene- $\mathrm{d}_{10}$ \\
\hline C1-Dibenzothiophenes & C1-DBT & 198 & Fluorene- $\mathrm{d}_{10}$ \\
\hline C2-Dibenzothiophenes, & C2-DBT & 212 & Fluorene- $\mathrm{d}_{10}$ \\
\hline Benzo $[b]$ naphtothiophenes & BNTs & 234 & Pyrene- $\mathrm{d}_{10}$ \\
\hline C1- Benzo $[b]$ naphtothiophenes & C1-BNTs & 248 & Pyrene- $\mathrm{d}_{10}$ \\
\hline \multicolumn{4}{|l|}{ O-PAH and alkylated homologues } \\
\hline Dibenzo $[b, d]$ furan & $\mathrm{DBF}$ & 168 & Fluorene- $\mathrm{d}_{10}$ \\
\hline C1 - Dibenzo $[b, d]$ furan & C1-DBF & 182 & Fluorene- $\mathrm{d}_{10}$ \\
\hline C2 - Dibenzo $[b, d]$ furan & C2-DBF & 196 & Fluorene- $\mathrm{d}_{10}$ \\
\hline
\end{tabular}




\section{Grain-size distribution and total organic carbon (TOC) of the sediment}

Grain-size distribution of the sediment was determined by the combined method of sieving and aerometric measurements as described by Casagrande (CASAGRANDE, 1948). Sediment was classified according to the Wentworth scale and presented as the amount of gravel $(>0,2 \mathrm{~mm})$, sand $(0,125-0,2 \mathrm{~mm})$ and mud $(<0,125 \mathrm{~mm})$ (WENTWORTH, 1922; FOLK, 1954). Mud was calculated as a sum of silt $(0,063-0,125 \mathrm{~mm})$ and clay $(<0,063)$. TOC in the sediment was determined by the combined method of chemical and thermal oxidation. Samples were treated with hydrochloric acid for one hour in order to remove carbonate fraction. Afterward, sediment samples were thermally oxidized in the furnace at $375{ }^{\circ} \mathrm{C}$ with an airflow rate of $200 \mathrm{ml} / \mathrm{min}$. TOC was finally determined upon the concentration of combustion-derived $\mathrm{CO}_{2}$.

\section{Assessment of PAHs origin}

PAHs origin was evaluated by calculation of concentration ratios between various $\mathrm{PAH}$ compounds. These ratios are often referred to as diagnostic ratios or diagnostic indices as their value is used to differentiate between various PAH sources. In order to accurately ascribe certain ratio value with a possible source of pollution, it is necessary to know the structure of PAH mixtures emitted from different sources. For this purposes, PAH mixtures generated during the combustion of different organic materials under different conditions were extensively studied which isolated PAH molecules that can be used as an indicator of origin. Concentration ratios of isomers with same molecular weight have been widely used in order to differentiate between petrogenic and pyrogenic PAH pollution (GRIMMER et al., 1981; GSCHWEND \& HITES, 1981; GUO et al., 2007; SICRE et al., 1987; BUDZINSKI et al., 1997;
YUNKER et al., 2002). These ratios are temperature dependent since PAH isomers formed during the low temperature process $\left(<200{ }^{\circ} \mathrm{C}\right)$ are more stable than the isomers formed during the hightemperature combustion. Therefore, prevalence of less stable isomer in PAH mixture indicates high-temperature process as the most probable source. Following isomer pairs of the same molecular weight were used: PHE/ANT, FLA/ $\mathrm{PY}, \mathrm{BaA} / \mathrm{CHR}$ and IP/BghiPer.

Other indicators for addressing $\mathrm{PAH}$ pollution sources are concentration ratios between parent PAHs and their alkylated counterparts (LEHNDORF \& SCHWARK, 2009; GSCHWEND \& HITES 1981; KIM et al., 2008; LUO et al., 2008; ELMQUIST et al., 2007). Unburned petroleum and other fossil fuels contain a significant amount of alkylated $\mathrm{PAH}$, thus, their dominance over unsubstituted homologues is a potential indicator of petrogenic origin of pollution. In this study, the relation between phenanthrene, pyrene, chrysenes and their alkylated homologues were studied in order to distinguish between different $\mathrm{PAH}$ source. Concentration ratio between total parent PAHs and total alkylated homologues had also been applied.

Finally, PAH origin was evaluated by application of pyrogenic index (PI) and fossil fuel pollution index (FFPI). Pyrogenic index (PI) is the ratio of the sum of the concentrations of unsubstituted 3-6 rings PAH, enlisted on EPA 16 priority list, to the sum of the concentration of the five alkylated homologues: naphthalenes, fluorenes, dibenzotiophenes, phenanthrenes and chrysenes (WANG et al., 1999b). PI values are higher for pyrogenic sources whereas for low PI values petrogenic sources are more likely.

Fossil fuel pollution index (FFPI) evaluates the contribution of fossil fuels to the PAH sediment concentrations using the ratio between the sum of characteristic petrogenic PAHs and total PAH concentration. Following mathematical expression was used for FFPI calculations:

$$
\text { FFPI }=\frac{N+C 1 N+C 2 N+C 3 N+C 4 N+D B T+C 1 D B T+C 2 D B T+\frac{P H E+C 1 P H E}{2}+C 2 P H E+C 3 P H E}{T P A H}
$$

Index values close to zero correspond with the most pyrogenic PAH mixtures while for the unburned fossil fuel this value is close to one

(IQBAL et al., 2008; STOUT et al., 2001b). Petrogenic sources contribution to overall PAH concentration increases as the index value increases. 


\section{RESULTS AND DISCUSSION}

\section{PAC concentrations and composition of PAC mixtures in sediments}

Concentrations of polycyclic aromatic hydrocarbons (PAH), sulfur containing heterocyclic aromatic compounds (S-PAH) and oxygen-containing heterocyclic compounds $(\mathrm{O}-\mathrm{PAH})$ determined on investigated stations are shown in Table 3. PAH concentrations ranged from $35,46 \mu \mathrm{g} \mathrm{kg}^{-1}$ (S4) to $2274,24 \mu \mathrm{g} \mathrm{kg}^{-1}$ (S1) whereas total concentration of polycyclic aromatic compounds (PAC) ranged from 39,93 $\mu \mathrm{g}$ $\mathrm{kg}^{-1}$ (S4) - 2663,27 $\mu \mathrm{g} \mathrm{kg}^{-1}$ (S1). Composition of PAC mixture with contributions of PAH, O-PAH and S-PAHs in the sediment of each station area shown in Fig. 2.

Highest PAC concentrations were measured on S1 station, situated in Kaštela Bay, where PAH accounted for $85,39 \%$ of total PAC concentrations in sediment (Fig. 2). High concentrations of PAC were also observed on S8 station, located approximately 20 miles from the Monte Gargano (Italian coast). PAH concentrations on this stations were $991,88 \mu \mathrm{g} \mathrm{kg}^{-1}$ contributing to total PAC concentrations with $93,43 \%$. PAHs were a dominant group on each station, contributing to total PAC concentration with more than $85 \%$. The highest PAH contribution were determined on S3 station where PAHs accounted for $94,89 \%$ of total PAC concentrations (Fig. 2).

Concentrations of total S-PAH in the investigated sediments ranged from $0,99 \mu \mathrm{g} \mathrm{kg}^{-1}$ (S6) to $344,68 \mu \mathrm{g} \mathrm{kg}^{-1}$ (S1). Higher concentrations were determined in sediments that are more close to the coastal zone where higher concentrations of total PAC were also measured (Table 3). In the

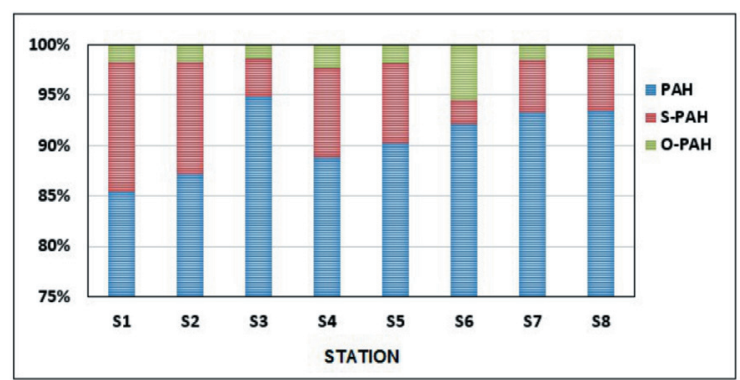

Fig. 2. Relative contributions of PAH, S-PAH and O-PAH to total PAC concentration in the investigated samples most of the samples, C1-BNTs were dominant S-PAH compound, except for the two stations in Kaštela Bay where the dominance of C2-DBT with concentrations of $92,13 \mu \mathrm{g} \mathrm{kg}^{-1}$ (S1) and $16,64 \mu \mathrm{g} \mathrm{kg}^{-1}$ (S2) was observed. Methylated DBT were dominant compounds on S4 station where C2-DBT concentrations were equal to C3-DBT concentration $\left(0,91 \mu \mathrm{g} \mathrm{kg}^{-1}\right)$.

If S-PAH contributions to total PAC concentration in sediments were observed (Fig. 2), it is evident that highest contributions of this fraction were found in coastal sediments where the highest absolute concentrations of S-PAH were also determined. On S1 station S-PAH attributed for $12,98 \%$ of total PAC concentration whereas on $\mathrm{S} 2$ station, this contribution was somewhat lower, $11,16 \%$ respectively. On S6 station, S-PAH contribution was the lowest $(2,31 \%)$ while on the rest of the stations, S-PAH contribution were within range $3,81-8,88 \%$. In general, concentrations and relative amounts of sulfur-containing PAC tended to decrease as the distance from the coast increased.

Concentrations of non-substituted DBF were higher than the concentrations of its methylated counterparts on the majority of the stations (Table 3). Concentration range for parent DBF was within 0,55 (S4) - 19,86 $\mu \mathrm{g} \mathrm{kg}^{-1}$ (S1) while sum of the methyl and dimethyl DBF ranged from 0,27 (S5) - 24,49 $\mu \mathrm{g} \mathrm{kg}^{-1}$ (S1). C1-DBF were found to be dominant O-PAH compounds only on S6 station. Similar to PAH and S-PAH, concentrations of O-PAH were higher on the stations that are closer to the coastal zone. On S1 station, $44,35 \mu \mathrm{g} \mathrm{kg}^{-1}$ of total O-PAH were measured, whereas on the S2 station O-PAH concentrations were $9,79 \mu \mathrm{g} \mathrm{kg}^{-1}$. Somewhat higher O-PAH concentrations were also found in the sediment of the S8 station $(13,84 \mu \mathrm{g}$ $\mathrm{kg}^{-1}$ ) while in the open sea stations (S4 and S5), O-PAH concentrations were below $1 \mu \mathrm{g} \mathrm{kg}^{-1}$.

Although the highest absolute concentrations of O-PAH were measured on $\mathrm{S} 1$ station, contributions of this fraction increased as the distance from the coast increased (Fig. 2). The highest contribution was observed on S6 stations where O-PAH accounted for 5,54\% of total PAC concentrations. Open sea sediments 
MANDIĆ et al.: Concentrations and origin of polycyclic aromatic hydrocarbons in sediments of the Middle ... 11

Table 3. Concentrations of polycyclic aromatic hydrocarbons, heterocyclic aromatic compounds of sulphur and oxygen ( $\mu \mathrm{g} \mathrm{kg-1)}$ with detection limits and recovery factors for two deuterated internal standards

\begin{tabular}{|c|c|c|c|c|c|c|c|c|}
\hline STATION & S1 & S2 & S3 & S4 & S5 & S6 & S7 & S8 \\
\hline Units & $\mu \mathrm{g} \mathrm{kg}^{-1}$ & $\mu \mathrm{gg}^{-1}$ & $\mu \mathrm{gg}^{-1}$ & $\mu \mathrm{kg}^{-1}$ & $\mu \mathrm{kg}^{-1}$ & $\mu \mathrm{g} \mathrm{kg}^{-1}$ & $\mu \mathrm{g} \mathrm{kg}^{-1}$ & $\mu g \mathrm{~kg}^{-1}$ \\
\hline LOD & $4,12 \mathrm{E}-04$ & $1,67 \mathrm{E}-04$ & $9,50 \mathrm{E}-05$ & $3,10 E-05$ & $3,40 E-05$ & $3,90 \mathrm{E}-05$ & $3,40 \mathrm{E}-05$ & $3,90 \mathrm{E}-05$ \\
\hline \multicolumn{9}{|l|}{ PAH } \\
\hline $\mathrm{Na}$ & 13,98 & 3,56 & 1,09 & 0,22 & 0,35 & 0,22 & 2,13 & 12,56 \\
\hline C1-N & 52,04 & 6,23 & 1,05 & 0,75 & 0,81 & 0,91 & 5,19 & 26,51 \\
\hline $\mathrm{C} 2-\mathrm{N}$ & 113,75 & 14,69 & 2,36 & 1,13 & 2,05 & 5,92 & 7,08 & 42,38 \\
\hline C3-N & 103,11 & 13,08 & 1,74 & 1,00 & 1,48 & 6,72 & 5,06 & 24,94 \\
\hline C4-N & 51,33 & 8,19 & 0,47 & 0,64 & 0,47 & 3,43 & 3,06 & 17,60 \\
\hline $\mathrm{ACY}$ & 2,31 & 0,54 & 0,19 & 0,00 & 0,06 & 0,00 & 0,15 & 0,86 \\
\hline ACE & 9,68 & 1,14 & 0,25 & 0,08 & 0,05 & 0,00 & 0,20 & 0,85 \\
\hline F & 17,50 & 3,22 & 0,78 & 0,18 & 0,23 & 0,20 & 0,43 & 4,27 \\
\hline $\mathrm{C1}-\mathrm{F}$ & 55,55 & 5,78 & 0,99 & 0,89 & 0,38 & 2,22 & 2,11 & 14,07 \\
\hline $\mathrm{C} 2-\mathrm{F}$ & 65,35 & 7,39 & 0,49 & 2,50 & 0,54 & 4,49 & 2,19 & 11,42 \\
\hline PHE & 90,44 & 20,75 & 8,05 & 1,21 & 1,98 & 1,13 & 7,21 & 19,81 \\
\hline ANT & 26,90 & 6,16 & 2,17 & 0,24 & 0,17 & 0,20 & 0,27 & 1,95 \\
\hline C1-PHE & 126,51 & 28,57 & 6,55 & 1,19 & 2,95 & 1,19 & 11,04 & 37,93 \\
\hline C2-PHE & 157,62 & 31,70 & 4,53 & 0,75 & 1,14 & 1,01 & 8,26 & 36,29 \\
\hline C3-PHE & 105,34 & 22,41 & 1,83 & 1,63 & 1,16 & 0,36 & 4,46 & 25,25 \\
\hline FLA & 122,58 & 34,23 & 12,48 & 1,90 & 1,15 & 0,73 & 3,27 & 17,33 \\
\hline PY & 120,44 & 32,57 & 10,46 & 1,45 & 1,27 & 0,77 & 3,13 & 21,00 \\
\hline RET & 35,48 & 9,32 & 2,18 & 0,43 & 0,45 & 0,16 & 1,66 & 22,37 \\
\hline C1-PY & 164,82 & 37,42 & 9,33 & 1,14 & 1,48 & 0,37 & 8,21 & 41,43 \\
\hline C2-PY & 121,78 & 17,51 & 2,95 & 1,50 & 1,25 & 0,00 & 4,36 & 21,85 \\
\hline $\mathrm{BaA}$ & 47,39 & 11,97 & 8,47 & 0,78 & 0,86 & 0,20 & 3,01 & 11,99 \\
\hline CHR & 65,08 & 11,28 & 9,09 & 1,07 & 1,16 & 0,38 & 4,23 & 11,89 \\
\hline C1-CHR & 89,54 & 20,53 & 5,15 & 1,03 & 1,19 & 0,25 & 5,15 & 28,90 \\
\hline C2-CHR & 92,55 & 12,99 & 2,76 & 1,00 & 1,07 & 0,00 & 5,01 & 35,82 \\
\hline C3-CHR & 21,34 & 3,25 & 0,00 & 0,01 & 0,51 & 0,00 & 1,06 & 15,63 \\
\hline BFL & 132,48 & 49,43 & 26,21 & 2,96 & 5,13 & 2,06 & 13,10 & 89,19 \\
\hline C1-BFL & 84,23 & 19,54 & 7,01 & 1,24 & 4,05 & 0,16 & 10,01 & 80,79 \\
\hline $\mathrm{BeP}$ & 44,85 & 16,91 & 8,67 & 1,12 & 1,42 & 0,28 & 5,40 & 36,34 \\
\hline $\mathrm{BaP}$ & 41,57 & 13,41 & 10,76 & 1,04 & 1,07 & 0,25 & 2,04 & 15,74 \\
\hline PER & 23,03 & 7,58 & 3,97 & 0,56 & 1,04 & 0,28 & 3,10 & 83,47 \\
\hline $\mathbb{P} \mathbf{P}$ & 25,85 & 12,55 & 8,21 & 1,86 & 3,06 & 1,07 & 7,18 & 40,45 \\
\hline DBA & 8,66 & 3,06 & 2,14 & 0,29 & 0,55 & 0,17 & 1,07 & 9,01 \\
\hline BPER & 13,83 & 9,47 & 7,28 & 1,13 & 1,85 & 0,51 & 4,03 & 25,85 \\
\hline DBP & 2,26 & 1,37 & 1,03 & 0,24 & 0,38 & 0,12 & 1,00 & 5,80 \\
\hline COR & 2,25 & 1,56 & 1,54 & 0,53 & 1,22 & 0,00 & 4,30 & 21,87 \\
\hline C1-302 & 22,83 & 10,63 & 9,16 & 1,78 & 3,88 & 4,01 & 15,77 & 78,46 \\
\hline \multicolumn{9}{|l|}{ S-PAH } \\
\hline DBT & 28,09 & 6,30 & 1,49 & 0,22 & 0,23 & 0,15 & 0,71 & 3,38 \\
\hline C1-DBT & 63,10 & 9,95 & 0,68 & 0,44 & 0,54 & 0,00 & 1,01 & 5,97 \\
\hline C2-DBT & 92,13 & 16,64 & 0,80 & 0,91 & 1,09 & 0,08 & 1,63 & 10,87 \\
\hline C3-DBT & 56,31 & 12,22 & 0,29 & 0,91 & 0,57 & 0,09 & 1,13 & 6,84 \\
\hline BNTs & 31,76 & 8,95 & 1,76 & 0,56 & 0,69 & 0,26 & 2,22 & 9,94 \\
\hline C1-BNTs & 73,29 & 11,13 & 2,25 & 0,50 & 1,10 & 0,41 & 2,38 & 18,45 \\
\hline \multicolumn{9}{|l|}{ O-PAH } \\
\hline DBF & 19,86 & 4,56 & 1,57 & 0,55 & 0,68 & 0,90 & 1,54 & 8,99 \\
\hline C1-DBF & 13,91 & 3,49 & 0,72 & 0,30 & 0,22 & 1,49 & 0,82 & 3,98 \\
\hline C2-DBF & 10,58 & 1,73 & 0,20 & 0,07 & 0,05 & 0,00 & 0,32 & 0,87 \\
\hline T-PAC & 2663,27 & 584,97 & 191,15 & 39,93 & 53,02 & 43,15 & 176,67 & 1061,17 \\
\hline Т-PAH & 2274,24 & 510,00 & 181,39 & 35,46 & 47,87 & 39,77 & 164,91 & 991,88 \\
\hline RF Phenanthrene $d_{10}(\%)$ & 87,3 & 89,1 & 72,60 & 70,30 & 75,80 & 81,70 & 78,70 & 70,17 \\
\hline RF Benzo[e] pyrene $d_{12}(\%)$ & 71,2 & 73,1 & 70,30 & 73,50 & 95,00 & 91,60 & 81,40 & 75,16 \\
\hline RF average (\%) & 79,25 & 81,1 & 71,45 & 71,9 & 85,4 & 86,65 & 80,05 & 72,67 \\
\hline
\end{tabular}


displayed higher contributions of O-PAH than stations near the coastal area, which was probably due to the different properties and different environmental behavior of O-PAH if compared with PAH. O-PAH are the most soluble group of polycyclic aromatic compounds; hence, their transport through sediment is enhanced if compared to other investigated groups. Furthermore, $\mathrm{O}-\mathrm{PAH}$ are intermediate products of PAHs biodegradation, thus enhanced biodegradation rates in the open sea sediment could be another reason for higher O-PAH contributions. If bottom morphology of the investigated area was taken into account, former explanation is more likely as it was shown that sea depth gradually increases towards the open sea but in the vicinity of the S3 station depth suddenly decreases forming a barrier for sediment exchange between coastal and open sea area (BOGNER \& MATIJEVIĆ, 2016).

Results show that absolute concentrations of heterocyclic compounds decreased when approaching open sea regions, which is due to the lower anthropogenic pressures on these stations if compared to the coastal ones. If, however, contributions of these groups to the total PAC concentration were observed, enrichment of the sediment with O-PAH in open sea regions is noticed whereas S-PAH contributions decreased as the distance from the coast increased. The probable explanation is that S-PAHs are released from the same sources as PAH, thus, areas with higher PAH concentration would also contain higher S-PAH concentrations.

Contrary to the S-PAH, O-PAHs show different environmental behavior than $\mathrm{PAH}$ compounds. The oxygen atom in O-PAH structure is responsible for the enhanced polarity of these compounds allowing more efficient transport through the water bodies. Furthermore, these substances are also formed by PAH degradation, thus, their concentration cannot be predicted upon PAH since O-PAHs are formed while PAHs are being degraded causing O-PAH concentrations to increase as $\mathrm{PAH}$ concentration decrease. (LUNDSTEADT et al., 2007).

The highest PAH concentrations were observed on S1 station, situated in the northeastern part of Kaštela Bay (Table 3). This station is nearest to the coast and is under intense anthropogenic pressures, mostly derived from transportation, industry and urban activities of the city of Split. Concentrations of PAH decreased as the distance from the Eastern coast increased, reaching minimal value on $\mathrm{S} 4$ station $(35,38$ $\left.\mu \mathrm{g} \mathrm{kg}^{-1}\right)$. Afterward, total PAH levels gradually increased by approaching the western Adriatic coast. Low PAH concentrations were measured on S4, S5, and S6 stations, located in the open sea area and most distant from both, Eastern and Western coast (Table 3).

Obtained results are in good accordance with earlier research of PAHs in the Adriatic. Similar PAH values were reported for the sediments along the western Adriatic coast (GUZELLA \& DE PAOLIS, 1994), for the Gulf of Trieste (NOTAR et al., 2001; HEATH et al., 2006) and for the coastal area of Chioggia and Ancona (MAGI et al., 2002.). Considerably higher PAH concentrations were reported for the areas under greater anthropogenic pressure such as Venice lagoon, with PAH concentration ranging from 184 to 201678 $\mu \mathrm{g} \mathrm{kg}^{-1}$ (FATTORE et al., 1997) and Bay of Rijeka where PAH concentrations were from 52 to $12532 \mu \mathrm{g} \mathrm{kg}^{-1}$. (ALEBIĆ-JURETIĆ, 2011) Although a lot of research of PAHs in northern and western Adriatic was performed, there is a lack of recent data on PAHs in sediments of the eastern Adriatic. This is especially true for the middle and south part of the eastern Adriatic where only one research on PAHs was conducted in the last three decades. Back then, maximum PAH concentration was $2000 \mu \mathrm{g} \mathrm{kg}^{-1}$ (DUJMOV et al., 1994) which was the total PAH concentration in the sediment of Kaštela Bay, measured by fluorimeter and expressed as Chrysene equivalents. Even though this method is less accurate and less sensitive when compared to mass spectrometry, obtained results were in good accordance with results provided by the current study. If compared with other parts of Mediterranean Sea, these results show that the most of the sediment PAH concentrations correspond with those reported for the Black Sea (WAKEHAM et al., 1996) and Eastern Mediterranean (TSAPAKIS et al., 2003). Obtained data are also in good accordance with PAH values reported for the world sea sedi- 
ments: low $\left(<100 \mu \mathrm{g} \mathrm{kg}^{-1}\right)$ or moderate $(100-500$ $\mu \mathrm{g} \mathrm{kg}^{-1}$ ) concentrations were found in the open sea sediments (SAVINOV et al., 2003; BAUMARD et al., 1998; GOGOU et al., 2000) whereas higher PAH concentration were typical for coastal regions. High PAH concentrations measured on S1 station, were still below the values reported for the areas of big coastal cities and harbors such as Barcelona harbor (BAUMARD et al., 1998) and Toulon harbor (BENLAHCEN et al., 1997).

\section{Composition of PAH mixture}

Concentrations of 20 parent $\mathrm{PAH}$ compounds and 16 groups of alkylated $\mathrm{PAH}$ isomers on three stations in the coastal zone are shown in Fig. 3.

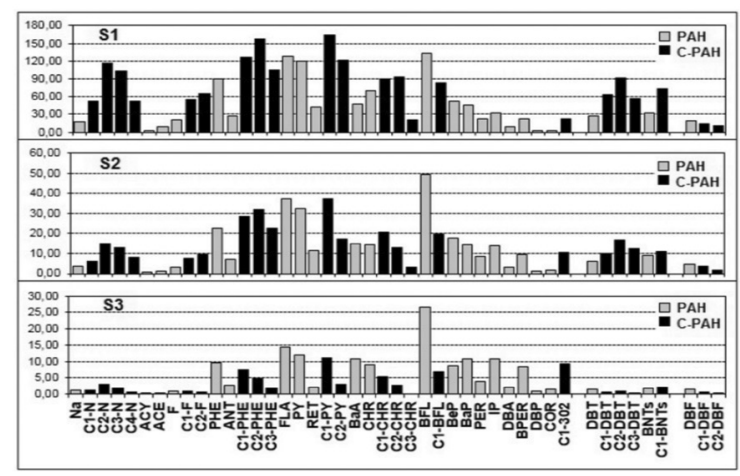

Fig. 3. Fingerprint pattern of polycyclic aromatic hydrocarbons determined for the three stations in the coastal zone

On S1 station, high concentrations of both, non-substituted PAH and methyl-PAH were determined with the dominance of methyl-PAH. The highest concentration was measured for C1-PY $\left(164,82 \mu \mathrm{g} \mathrm{kg}^{-1}\right)$ while C2-PHE concentration was slightly lower $\left(157,62 \mu \mathrm{g} \mathrm{kg}^{-1}\right)$. Among parent $\mathrm{PAH}$, dominant compounds were BFL $\left(132 \mu \mathrm{g} \mathrm{kg}^{-1}\right)$, FL $\left(127,58 \mu \mathrm{g} \mathrm{kg}^{-1}\right)$ and PY $\left(120,44 \mu \mathrm{g} \mathrm{kg}^{-1}\right)$. The dominance of methylsubstituted PAH, observed on S1 station, is in contrast with the data usually obtained for the coastal sediments and is probably caused by the greater amount of methyl-substituted PAH released during the accidental spills of petrochemical products from nearby shipyard and port. On S2 stations BFLs were dominant PAH compounds in the mixture with the concentra- tion of $49,32 \mu \mathrm{g} \mathrm{kg}^{-1}$ (Fig. 3). Similar to the S1, PAH mixture on this station was also enriched on alkyl-PAH especially on C1-PY $(37,42 \mu \mathrm{g}$ $\mathrm{kg}^{-1}$ ) and methyl-substituted phenanthrenes. PAH fingerprint pattern for S2 station is similar to the pattern for S1 station although dominance of alkylated PAHs was less expressed. S3 station was the only station in the investigated area with the total concentration of parent PAH compounds being higher than the concentration of their methylated homologues. On this station, dominant compounds in PAH mixture were BFL (26,61 $\mu \mathrm{g} \mathrm{kg}^{-1}$ ) while C1-PY and C1-302 were dominant methyl-substituted PAH. PAH fingerprint pattern on this station differs from those on S1 and S2 station containing mostly heavier $\mathrm{PAH}$ compounds with five and six rings in the structure such as Bep, BaP, IP and BPER. The differences in $\mathrm{PAH}$ fingerprint pattern between S3 and other coastal station suggest there are different kind of activities on S3 station, and consequently, different composition of PAH mixtures. Most intense activities on this station are marine transport and inland activities from the nearby islands. The other suspected sources of PAH are assumed to be the fire forests that often occur on the nearby island during the summer seasons. Bottom morphology of this area shows that there is a natural submarine barrier on this site, restricting the normal sea circulation resulting in pollutants accumulation in this area (BOGNER \& MATIJEVIĆ, 2016).

Fig. 4 shows PAH fingerprint patterns determined on stations located in the open sea area. PAH concentrations in the open sea sediments were considerably lower than those in the coastal sediments. On S4 station, BFL were compounds with the highest concentrations in the mixture $\left(2,96 \mu \mathrm{g} \mathrm{kg}^{-1}\right)$. Sediment was also enriched with C2-F $\left(2,5 \mu \mathrm{g} \mathrm{kg}^{-1}\right)$, C1-PHE $\left(1,19 \mu \mathrm{g} \mathrm{kg}^{-1}\right)$ and C1-302 $\left(1,78 \mu \mathrm{g} \mathrm{kg}^{-1}\right)$. BFL with concentration of 5,13 $\mu \mathrm{g} \mathrm{kg}^{-1}$ and their methylated homologues (C1-BFL), with a concentration of $4,05 \mu \mathrm{g} \mathrm{kg}^{-1}$, were found to be dominant compounds in the sediment of S5 station (Fig. 4). On this station, PAH mixture was also enriched with $\mathrm{C} 1-302$ $\left(3,88 \mu \mathrm{g} \mathrm{kg}^{-1}\right)$ and IP $\left(3,06 \mu \mathrm{g} \mathrm{kg}^{-1}\right)$.

Methyl-naphthalenes were dominant PAH compounds on S6 station where $6,72 \mu \mathrm{g} \mathrm{kg}^{-1}$ of 


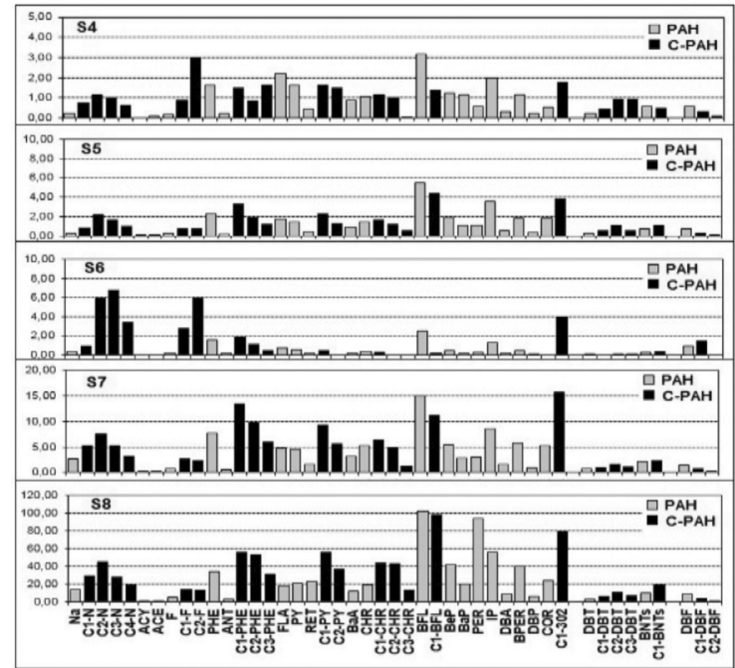

Fig. 4. Fingerprint pattern of polycyclic aromatic hydrocarbons determined for the stations in open sea area

C3-N accounted for $16,91 \%$ of total PAH concentration. The concentration of $\mathrm{C} 2-\mathrm{N}$ was 5,92 $\mu \mathrm{g} \mathrm{kg}^{-1}$ which was equal to the concentration of $\mathrm{C} 2-\mathrm{F}$, contributing to total $\mathrm{PAH}$ concentration with $14,88 \%$ each. Naphthalene and its alkylated homologues, as the smallest PAH molecules, are the least stable among all PAH compounds. The half-life of naphthalene in marine sediments is 0,3 days - 129 days whereas for the more complex PAH compounds this time is much longer; e.g. half-life of benzo $[a]$ pyrene is 3-58 years depending on environmental conditions such as temperature, oxygen amount and microbial populations (PAGE et al., 1993). Due to the low persistence toward degradation, high naphthalene concentrations could indicate pollution of more recent dates, although caution is advised when interpreting naphthalenes concentration, as these compounds are the most common laboratory contaminant. Dominant $\mathrm{PAH}$ compounds in sediment of S7 station were C1-302 $(15,77 \mu \mathrm{g}$ $\left.\mathrm{kg}^{-1}\right)$, followed by BFL $\left(13,10 \mu \mathrm{g} \mathrm{kg}^{-1}\right), \mathrm{C} 1$-PHE $\left(1,19 \mu \mathrm{g} \mathrm{kg}^{-1}\right)$ and C1-BFL $\left(10,01 \mu \mathrm{g} \mathrm{kg}^{-1}\right)$.

BFL, with a concentration of $89,19 \mu \mathrm{g} \mathrm{kg}^{-1}$, were dominant $\mathrm{PAH}$ on S8 station, followed by $\mathrm{C} 1-\mathrm{BFL}$ with a concentration of $80,77 \mu \mathrm{g}$ $\mathrm{kg}^{-1}$. High concentrations were also observed for a $\mathrm{C} 1-302$ fraction $\left(78,46 \mu \mathrm{g} \mathrm{kg}^{-1}\right)$. Perylene concentration on S8 station was $83,47 \mu \mathrm{g} \mathrm{kg}^{-1}$ contributing to total $\mathrm{PAH}$ concentration with
$8,42 \%$ which can be a potential indicator of biogenesis on this location as perylene is naturally produced by bacterial activity (PAGE et al., 1996; TOLOSA et al., 2004; LIMA et al., 2005).

When summarized, obtained results show that BFL were dominant $\mathrm{PAH}$ compounds on the majority of the investigated station. These compounds are emitted in high extent from automobile exhaust and coke combustion process and are typically used as an indicator of pyrogenic origin (LEHNDORF \& SCHWARK, 2009; KIM et al., 2008; LUO et al., 2008; ELMQUIST et al., 2007). However, BFL can also originate from natural sources such as vascular land plants production or termite activity (TOBISZEWSKI \& NAMIESNIK, 2012). It is assumed, however, that BFL are of anthropogenic origin as their dominance in the open sea sediments can be hardly linked to terrestrial activities. Contributions of C1-302 were also high in all sediment samples. Absolute concentrations of this fraction decreased as the distance from the coast increased, while on the contrary, relative amounts of C1-302 fraction increased as the distance from the eastern coast increased. The highest contribution was observed on S6 station where C1-302 accounted for $10,09 \%$ of total PAH. C1-302 contributions were also high on S5 (8,11\%) and S7 (9,57\%). The lowest contribution was observed on S1 station, where this fraction accounted for only $1,01 \%$ of total PAH concentrations. C1-302 fraction contains methylated isomers of $\mathrm{PAH}$ with six rings in their structure. This is the heaviest crude oil fraction typically contained in fuel oil and bituminous resins (STOUT \& WANG, 2007). Because the higher contributions of this fraction were observed in open sea sediments, it could be assumed that C1-302 originate from ship fuel since marine transport is the most intense anthropogenic activity in the open sea regions. Increased relative amount of this fraction in the open sea sediments could be also explained by its high persistence. Degradation rates of PAH decrease with increased molecular weight of the compound, causing enrichment of sediment with heavier PAH fraction (NEFF, 1978; NRCC, 1983). In vitro tests of PAH behavior in sediments under different environmental conditions 
demonstrated that high salinity values (above $37 \%$ or equal) negatively affect degradation rates of PAH compounds (MARINI \& FRAPACINI, 2013). Molecules with higher molecular weight were more influenced by salinity fluctuations, although persistence of all PAH compounds toward degradation was enhanced at higher salinity values. Enhanced persistence of PAH toward degradation in the areas with higher salinity could be the reason for sediment enrichment with heavier PAH compounds in the open sea regions since the coastal zone is more influenced by the riverine inputs resulting in lower salinity in this area (MEANS, 1995; MARINI \& FRAPACINI, 2013).

Perylene is considered as PAH of natural origin that is formed from biogenic precursors, although a considerable amount of perylene is also produced during the combustion (LIMA et al., 2005). If perylene contribution to the total concentration of 5-rings $\mathrm{PAH}$ is greater than $10 \%$, it can be considered of natural origin. $\mathrm{PAH}$ mixtures emitted during the combustion typically contain a small amount of perylene when compared to other $\mathrm{PAH}$ with 5 rings in their structure (PAGE at al., 1996; TOLOSA et al., 2004). Perylene contribution in total 5-ring PAH concentration was smaller than $10 \%$ at each station except for S8 station, where perylene accounted for more than $40 \%$ of total 5-rings PAH concentration, indicating the natural origin of this compound. This result also suggests strong biogenic/diagenetic activity on this station as these two processes are considered the main natural perylene sources.

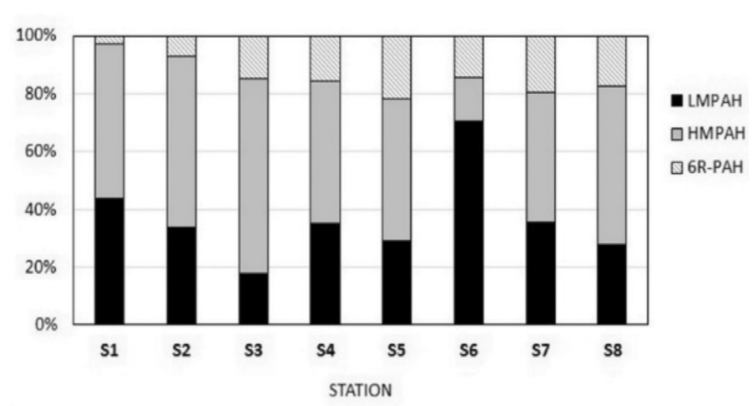

Fig. 5. Relative amounts of PAHs with low molecular weight (LMPAH), PAHS with high molecular weight (HMPAH) and PAHs with 6 rings (6R-PAH) in the structure
The relative amount of low molecular weight PAHs - LMPAH (2 and 3 ring PAH), high molecular weight $\mathrm{PAH}$ - HMPAH (4 and 5 ring PAH) and 6-ring $\mathrm{PAH}$ in the investigated samples are shown in Fig. 5. High LMPAH contributions to total PAH concentration in sediments were determined on S6 station, where this fraction accounted for $70,41 \%$ of total PAH concentration; and S1 station, where LMPAH accounted for $43,59 \%$. The lowest contribution of this fraction was observed on S3 station where LMPAH accounted for $17,94 \%$ of total PAH concentrations. On the rest of the investigated stations, LMPAH contributions to total PAH concentration in sediments were higher than $20 \%$. This light PAH fraction is a typical component of unburned fossil fuels and other petroleumderived products and usually indicates $\mathrm{PAH}$ mixtures of petrogenic origin (PAGE et al., 1996; STOUT \& WANG, 2007). If compared to HMPAH, this fraction is more susceptible to both, biodegradation and photodegradation, which is the reason for the enrichment of the sediments with heavier PAH fraction during the time (NEFF, 1979; SICRE et al., 1987). If this was taken into account, it can be assumed that PAH pollution on $\mathrm{S} 1$ and S6 station was either of petrogenic origin or pollution of more recent dates. The highest contribution of HMPAH fraction was observed on S3 station $(67,1 \%)$ and S2 station (59\%) whereas the lowest HMPAH contribution was observed on S6 station. (15,2\%) On other investigated station, HMPAH were dominant PAH compounds in the mixture contributing to total PAH concentration with more than $40 \%$. PAH fingerprint pattern with the dominance of HMPAH is typical for the industrialized and urbanized coastal areas where intense anthropogenic pressures are present (WAKEHAM et al., 1996; BENLACHEN et al., 1997; STORELLI \& MARCOTRIGIANO, 2000). The dominance of this fraction in the open sea sediments is more likely caused by greater persistence of HMPAH to degradation, causing sediment enrichment with heavier PAH compounds during the time. Relative contributions of 6-ring PAH fractions were higher in the open sea sediments with the maximum value determined on S5 station, where $21,7 \%$ of total PAH concen- 
tration were ascribed to 6-ring PAH. Relatively high contributions of this fraction were also observed on S7 (19,6\%) and S8 station $(17,4 \%)$. In Kaštela Bay, contributions of 6-rings fraction was the lowest: only $2,9 \%$ of total PAH concentration were ascribed to this fraction on $\mathrm{S} 1$ station and $7 \%$ on $\mathrm{S} 2$ station. Six-rings $\mathrm{PAH}$ are the heaviest PAH fraction investigated in this study and is typically formed during the high-temperature combustion (GSCHWEND \& HITES, 1981; KIM et al., 2008; LUO et al., 2008, ELMQUIST et al., 2007; LEHNDORF \& SCHWARK, 2009). During the crude oil distillation, 6-ring PAH will be present in the heavier fractions such as diesel fuel, heating oil and distillation resins that are typically used for ship fuels, therefore this fraction was suspected to originate from a fuel combustion in ship engines or from accidental fuel spillage on the sea surface (STOUT \& WANG, 2007).

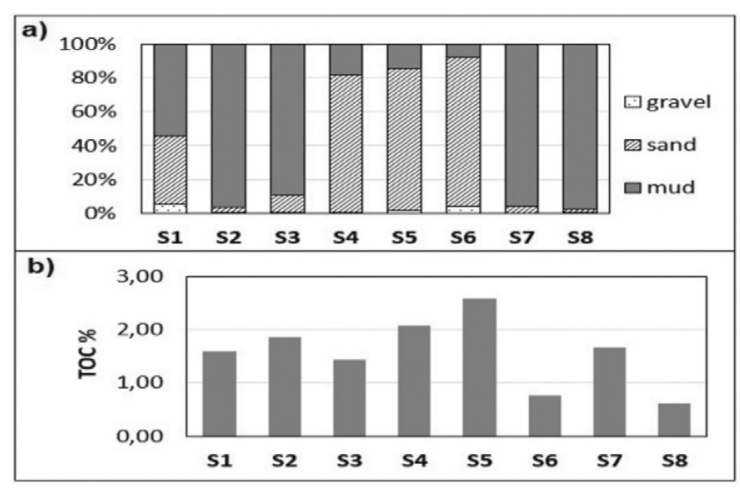

Fig. 6. Grain-size distribution and total organic carbon (TOC) in the sediments of the investigated stations

\section{Polycyclic aromatic hydrocarbons in relation to sediment particle size and total organic carbon}

Grain-size distribution of sediment and total organic carbon (TOC) of investigated sediments are shown in Fig. 6.

Gravel content, ranging from $0 \%$ (S7) to $5,6 \%$ (S1), was the least abundant size fraction in sediments. Somewhat higher amounts of gravel were found on S5 $(1,68)$ and S6 $(3,91)$ while on the other stations, gravel amount was lower than 1\% (Fig. 6a). Sand particles were dominant in sediments of S4, S5 and S6 sta- tion while on the other investigated stations dominant sediment fraction was mud. Coastal stations typically contain a higher amount of fine fraction, mainly due to the Jadro River inputs of fine grain material originating from the land. Anthropogenic activities also contribute to increased level of fine particles in sediments. These results are in good accordance with previous research studies conducted in Kaštela Bay (BOGNER \& MATIJEVIĆ, 2016) and other regions of the Adriatic Sea, where higher amounts of mud particles were usually observed in the coastal region. The high amount of muddy particles in the sediments of S7 $(95,97 \%)$ and S8 stations $(97,72 \%)$ is probably due to riverine inputs of fine grain materials. These two stations are nearest to the western Adriatic coast and nearest to the Po River delta. Rivers of the Po valley are known for introducing high amounts of landbased material, which is further spread, by the sea currents. This material is enriched with the fine size particles and consequently influences grain size distribution and sediment properties in the western Adriatic (RAVIAOLI et al., 2008; BOGNER \& MATIJEVIĆ, 2016). The sand fraction was dominant on S4 $(81,10 \%)$, S5(83,74\%) and S6 $(87,92 \%)$ which are the most remote stations from the coast. Open-sea sediments contain smaller amount of fine grain particles due to the greater distance from riverine inputs and anthropogenic pressures. Sediment in the open-sea regions was enriched with sandy fraction, which is partly a natural state of the open sea sediments and the erosion of the nearby islands further contributed to it (RAVIAOLI et al., 2008; BOGNER \& MATIJEVIĆ, 2016).

TOC values were higher in the open sea sediments (Fig. 6b) than in the coastal zone. Maximum TOC value was observed on S5 station $(2,59 \%)$ whereas the lowest PAH values were measured on S8 station. TOC values were not correlated with determined PAH concentration since higher TOC values were observed in the open sea sediments where PAH concentrations were the lowest. If low TOC value on the S8 station was observed along with the perylene concentration, it can be assumed that enhanced biological activity in the sediment results in 
greater biological uptake of organic carbon for the biosynthesis causing lower TOC content of the sediment (PAGE et al., 1996; TOLOSA et al., 2004). Absent correlation between PAH concentrations and TOC in sediments could be ascribed to their different origin since TOC is a natural component of the sediment, whereas most of the PAHs are of anthropogenic origin.

\section{Assessment of PAH origin by application of diagnostic ratios}

Concentration ratios of PHE/ANT, FLY/PY, $\mathrm{BaA} / \mathrm{CHR}$, IP/BPER, calculated for the investigated samples are shown in the form of double concentration plots in Fig. 7.

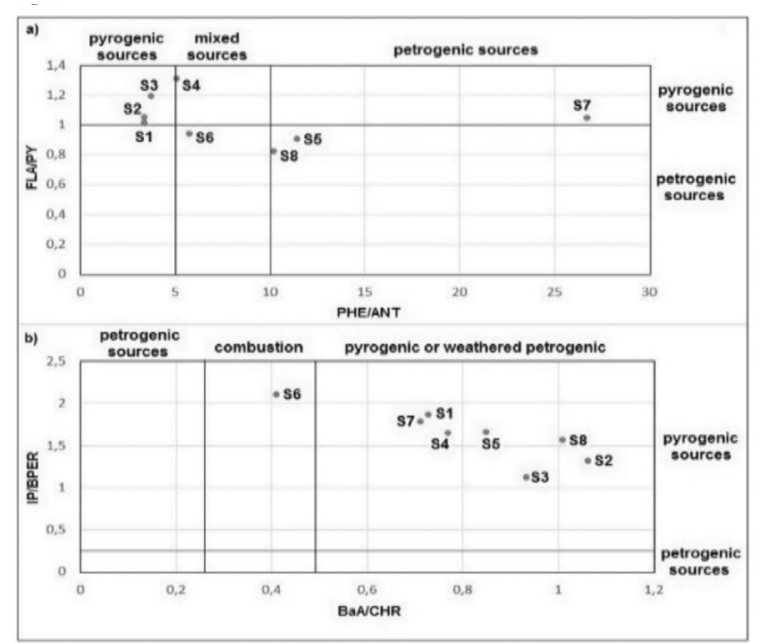

Fig. 7. Concentration ratios PHE/ANT, FLY/PY, BaA/CHR, IP/BPER presented as a double plots of a) PHE/ANT vs FLA/PY, b) BaA/CHR vs IP/BPER

Phenanthrene, as the most stable 3-rings $\mathrm{PAH}$, is produced during the conversion of organic matter in petroleum components and its prevalence over anthracene is commonly considered as an indicator of petrogenic pollution (GOGOU et al., 2000; DE LUCA et al., 2004: LIMA et al., 2005). Therefore, low values of PHE/ANT ratio are more likely for the combustion process, whereas high ratio values indicate petrogenic pollution. Ratio values calculated for the sediments of S5 $(11,44)$, S7 $(26,72)$ and S8 $(10,18)$ station indicated the dominance of petrogenic sources. In sediments on S1, S2 and S3 stations, low PHE/ANT ratios of 3,36 (S1), 3,37 (S2) and
3,71 (S3) corresponded with pyrogenic sources whereas on the S4 and S6 station ratio values indicated equal contributions of both, petrogenic and pyrogenic sources. Stations S1, S2 and $\mathrm{S} 3$ being situated in the coastal area are more influenced by industrial and urban activities than other investigated stations, thus, sediment enrichment with anthracene can be ascribed to the combustion process. On the rest of the investigated stations, contribution of petrogenic sources was greater, especially on the S7 station where ratio value of 26,72 strongly suggest petrogenic pollution.

FLA/PY ratio is also thermodynamically derived ratio commonly applied to distinguish between different PAH sources. Fluoranthene, as a less stable isomer, is preferably formed during the high-temperature process while on the contrary, pyrene is suspected to be the product of petrogenesis (SICRE et al., 1987; BUDZINSKI et al., 1997). Therefore, low FLA/PY ratio $(<1)$ are commonly attributed to pyrogenic sources and ratios higher than 1 to the petrogenic sources. When applied, these criteria suggest petrogenic source of pollution in sediments on S5 $(0,91)$, S6 $(0,94)$ and $\mathrm{S} 8(0,86)$ station whereas on the other investigated stations, FLA/PY ratio indicates the pyrogenic origin of PAH. If these results are compared to those obtained by application of PHE/ANT ratio it is seen that result for S1, $\mathrm{S} 2, \mathrm{~S} 3, \mathrm{~S} 4, \mathrm{~S} 5$ and S8 stations overlap with the result of PHE/ANT ratios while on the rest of the investigated stations slightly different results are observed.

$\mathrm{BaA} / \mathrm{CHR}$ ratio values were within the 0,41 (S6) and 1,06 (S2) range. During the combustion process, $\mathrm{BaA}$ is preferentially produced over chrysene, which enables differentiation between petrogenic and pyrogenic sources (YUNKER et al., 2002; DE LUCA et al., 2004). Criteria adopted in this study were as follows: $\mathrm{BaA} / \mathrm{CHR}<0,25$ indicated petrogenic sources, $0,25<\mathrm{BaA} / \mathrm{CHR}<0,5$ is for petroleum combustion and $\mathrm{BaA} / \mathrm{CHR}>$ 0,5 indicated other combustion processes (YUNKER et al., 2002). According to this, PAH mixtures in all samples originate from pyrogenic sources. De Luca proposed higher transition point from petrogenesis to pyrogenesis, suggesting that 
$\mathrm{BaA} / \mathrm{CHR}$ ratio $<1$ indicate petrogenesis while ratios $>1$ indicate pyrogenesis (DE LUCA et al., 2004). When this suggestion was taken into consideration it can be concluded that PAH mixtures in sediment at the majority of investigated stations are petroleum derived, except for S2 and S8 station, where ratio values of 1,06 and 1,01 indicated the pyrogenic origin of PAH. Results derived by application of $\mathrm{BaA} /$ CHR ratio differ from the previously obtained results. These differences can be ascribed to the different behavior of PAH compounds during the weathering. $\mathrm{BaA}$ is more suspected to the process of photolysis and shows different environmental behavior than CHR (YUNKER et al., 2002; TOBISZEWSKI \& NAMIESNIK, 2012). As a less stable isomer, BaA converts to Chrysene during degradation, reducing the ratio value; therefore, caution has to be applied when using this ratio for weathered pollution (SOCLO et al., 2000; YUNKER et al., 2002; STOUT et al., 2003).

IP/BPER ratio indicated pyrogenic sources of PAH in sediment samples of each investigated station. Inconsistency of the result obtained by application of this ratio with three previously applied criteria is probably due to the different behavior of these two PAHs in the atmosphere. Atmospheric degradation of these isomers is highly influenced by the particle association: degradation rates are the same for both isomers when attached on black particles whereas IP degrades faster than BPER when attached to gray particles and much slower when attached to white particles (BEHYMER \& HITES, 1998).

Concentration ratios between following pairs of compounds: C1-PHE and PHE; C1-PY and PY; CHR and C2-CHR and C-PAH/PAH, are shown in Fig. 8. Phenanthrene will dominate over its methyl-homologues in PAH mixture formed during the combustion (LEHNDORF \& SCHWARK, 2009); although, combustion at low temperature also preserves petrogenic alkylation pattern. Some petrogenic sources, such as petroleum oil shales and their refined products may also obtain C1-PHE/PHE ratio values higher the two (GSCHWEND \& HITES, 1981; KIM et al., 2008; LUO et al., 2008). When C1-PHE/PHE value is smaller than one, pyrogenic sources are more likely (ELMQUIST et al., 2007). Heavy petroleum fractions, such as creosote and coal tar also show low C1-PHE/PHE ratio $(<0,2)$ while ratios values $1-2$ correspond to both, petrogenic and pyrogenic sources, and can be ascribed to coal, automobile exhaust, motor oils and used lubricants (ELMQUIST et al., 2007). In this study, $\mathrm{C} 1-\mathrm{PHE} / \mathrm{PHE}$ ratios $<0,2$ are ascribed to coal tar and creosote; values in the range $0,2-1$ to pyrogenic sources; values $1-1,5$ to mixed sources while ratios higher than 1,5 were ascribed to unburned petroleum (Fig. 8a). According to this ratio, combustion was the dominant source of PAH in sediments at S3 $(0,82)$ station while unburned petroleum was dominant $\mathrm{PAH}$ source on following stations: S5 $(1,53)$, S6 $(1,65)$, S7 $(1,77)$ and $S 8(2,66)$. Mixed sources were identified on S1, S2 and S4 station.

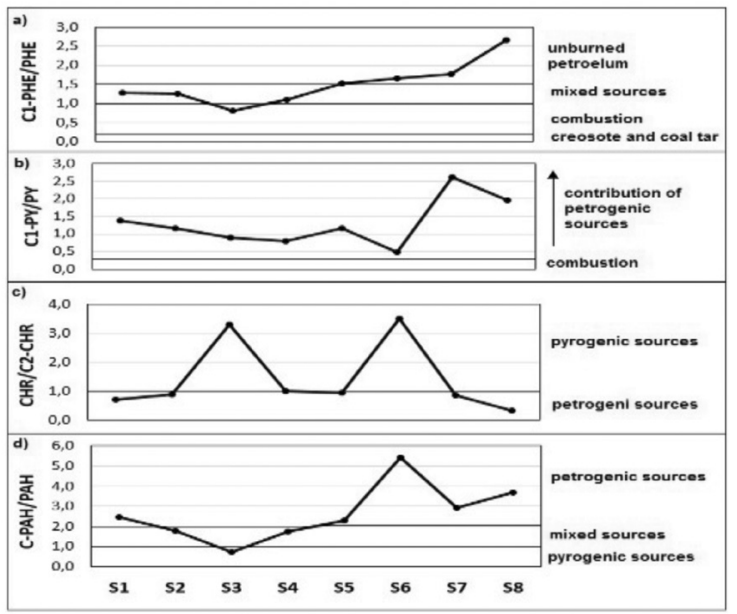

Fig. 8. Concentration ratios of: a) C1-PHE and PHE b) C1-PY and PY, c) CHR and C2-CHR d) total alkylsubstituted total PAHs and PAHs; in the investigated samples

Low C1-PY/PY ratio values indicate pyrogenic source while higher values indicate petrogenic source of pollution. Higher the ratio, contribution of the petrogenic sources is higher (BUCHELI et al., 2004). When applied, this ratio values showed the greatest contribution of pyrogenic sources on the S6 station (Fig. 8b) while unburned petroleum is the most likely source of pollution on S7 station. Ratio values corresponding with petrogenic sources were also observed on the S8 $(1,98)$ and $\mathrm{S} 1(1,37)$ station while on the rest of the investigated stations pyrogenic sources were the main source of PAH pollution. 
PAH mixtures emitted from pyrogenic sources typically show CHR/C2-CHR ratios higher than one whereas low ratio values $(<1)$ indicate petrogenic pollution (STOUT et al., 2004). According to this ratio, petrogenic sources are dominant on the most of the investigated station (Fig. 8c), except for S3 and S6 station where high ratio values ( $>3$ ) strongly suggest the dominance of pyrogenic sources. Another indicator based on chrysene and alkyl-chrysene concentrations is a relation between concentrations of chrysene and its alkyl-isomers. In mixtures formed during the combustion, chrysene concentrations are higher than C1-chrysene and tend to decrease as the degree of alkylation increase. Thus, in case $\mathrm{CHR}>\mathrm{C} 1-\mathrm{CHR}>\mathrm{C} 2-\mathrm{CHR}>\mathrm{C} 3-\mathrm{CHR}>\mathrm{C} 4-\mathrm{CHR}$, $\mathrm{PAH}$ are considered to be of pyrogenic origin while on the contrary, if the concentration of any methylated chrysene group is higher than a concentration of parent chrysene, the dominance of petrogenic sources is indicated (WANG et al., 1999b). These criteria confirmed results provided by $\mathrm{CHR} / \mathrm{C} 2-\mathrm{CHR}$ ratio: $\mathrm{PAH}$ mixtures on $\mathrm{S} 3$ and $\mathrm{S} 6$ stations are mainly from pyrogenic sources while on the other station domination of petrogenic sources is observed (Table 3).

$\mathrm{C}-\mathrm{PAH} / \mathrm{PAH}$ ratio was successfully applied in order to discriminate between petrogenic and pyrogenic sources of PAH pollution over large geographic areas and during the long timespans (YAN et al., 2006). It was shown that pyrogenic sources produce $\mathrm{PAH}$ mixtures with low ratio values, lower than one, respectively. Petroleum combustion yields the highest ratio value of 1.1 and it is an upper limit for the pyrogenic sources, whereas coal combustion produces mixtures with a ratio value of 0,35 (YAN et al., 2007). PAH compounds taken into account for this ratio were PAH with molecular masses of 128,178 , 202 and 228, respectively. Ratio values for the investigated sediments indicated the dominance of pyrogenic sources only on S3 station (Fig. $8 \mathrm{~d}$ ). The petrogenic source of pollution were the most important PAH sources on S1,S5,S6, S7 and S8 station while on the S2 and S4 station equal contribution of petrogenic and pyrogenic sources was determined (Fig. 8d).

The pyrogenic index is the ratio of the sum of the concentrations of unsubstituted 3-6 PAHs, enlisted on EPA 16 priority list, to the sum of the concentration of the five alkylated homologues: naphthalenes, fluorenes, dibenzotiphenes, phenanthrenes and chrysenes (WANG et al., 1999b). PI values are higher for pyrogenic sources whereas low PI values indicate petrogenic pollution. According to this ratio (Fig. 9.), PAH mixtures on S3 were of pyrogenic origin while on the other investigated station, prevalence of petrogenic sources was observed, especially on S1, S6 and S7 station where index values were as follows: 0,28 (S1), 0,18 (S6) and 0,54 (S7).

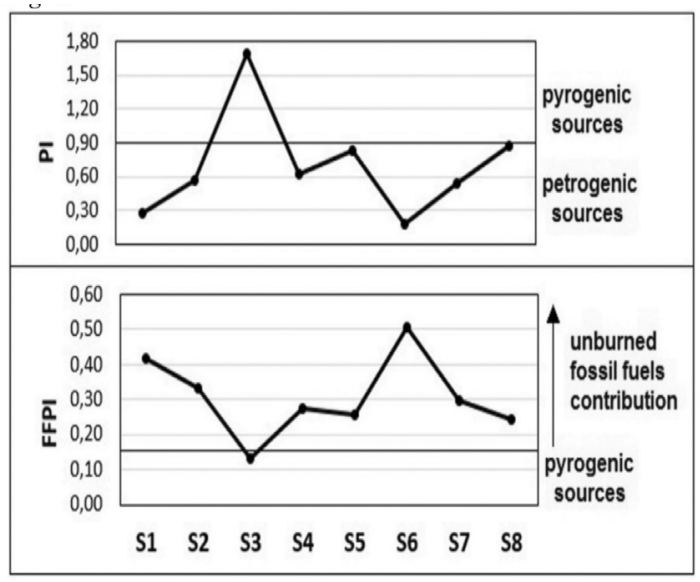

Fig. 9. Pyrogenic index (PI) and fossil fuel pollution index (FFPI) determined in the investigated samples

FFPI was the last index used for PAH source apportionments. Index values close to zero correspond with the most pyrogenic PAH mixtures while for the unburned fossil fuel this value is close to one (IQBAL et al., 2008). Petrogenic sources contribution to overall PAH concentration increase as the index value increases. FFPI index indicated the dominance of pyrogenic sources only on S3 station. High petrogenic PAH contributions were observed on S1 and S6 station while on the other investigated station index values showed a slightly higher contribution of petrogenic sources over pyrogenic ones.

\section{CONCLUSIONS}

Total PAC concentrations in the investigated area ranged from 39,93 (S4) to 2663,27 (S1). PAHs were a dominant group on each station contributing to the total PAC concentration with 
more than $85 \%$. Parent PAH compounds were found to be dominant PAH fraction only on S3 station. Total concentrations of both, PAC and $\mathrm{PAH}$, decreased as the distance from the coast increased, reaching minimum value on S4 station. Absolute concentrations of heterocyclic aromatic compounds also decreased as the distance from the coast increased, but contributions of O-PAHs in total PAC concentrations increased with the distance, being highest in the open sea sediments. This was mainly ascribed to the biologically mediated conversion of $\mathrm{PAH}$ into O-PAH during the degradation and it was probably further contributed by transportation of O-PAH from coastal zone. In the most of investigated stations, BFL and C1-302 were dominant $\mathrm{PAH}$ compounds, although dominance of methyl-PAH was observed at all station except for S3. Marine traffic was suspected to be the most likely reason for BFL dominance in the open sea sediments since BFL are emitted in large amounts during the fuel combustion in engines. The C1-302 fraction is also suspected to be transportation-derived as this fraction is the heaviest product of petroleum distillation commonly used as ship fuel. Due to the high molecular weight, C1-302 fraction is the least degradable one implying that sediments will be enriched with this fraction since the concentrations of the lighter PAH compounds tend to decrease due to degradation. The high amount of perylene measured on S8 station suggests enhanced biological activity at this location. Grain-size analyses showed that fine, muddy particles were dominant sediment fraction in coastal areas whereas in the open sea area sediments were enriched in sandy fraction. These findings are in good accordance with other research in which coastal sediments contain an elevated amount of muddy particles due to the riverine input of land-based materials. Sediment grain-size distribution determined in this study is also in good accordance with results of previous research studies on sediments of the Adriatic Sea. Although PAH concentrations were higher in the sediments with enhanced amount of fine particles, this cannot be ascribed to differences in mud content as the intense activities in the coastal zone are more likely responsible for elevated PAH concentrations. Diagnostic ratios strongly suggest petrogenic origin on S1, S5, S7, and $\mathrm{S} 8$ station where the petrogenic origin was indicated by six or more applied criteria. Pyrogenic origin was determined only on $\mathrm{S} 3$ station where 10 out of 11 applied criteria corresponded to pyrogenic sources. Equal contribution of both, petrogenic and pyrogenic sources was determined on S2, S4 and S6 station. Data presented here are preliminary results of more complex research of polycyclic aromatic compounds in the Adriatic Sea. Additional investigations on PAH origin, sediment properties, toxicity and seasonal changes in PAH concentrations will be presented in the future papers.

\section{ACKNOWLEDGEMENTS}

This study was financially supported by grants funded by French national agency for the promotion of higher education, international student services, and international mobility "Campus France". Jelena MANDIĆ wishes to express her gratitude to Jacek TRONCZYNSKI and Nadege BELY for their assistance and support during the scientific visit at IFREMER institute. Authors would also like to thank the crew of the research vessel R/V "BIOS DVA" for their help during the fieldwork. 


\section{REFERENCES}

ALEBIĆ-JURETIĆ, A. 2011. Polycyclic aromatic hydrocarbons in marine sediments from the Rijeka Bay area, Northern Adriatic, Croatia, 1998-2006. Mar. Pollut. Bull., 62: 863-869.

ANĐELIĆ, I., S. MATIJEVIĆ \& I. UJEVIĆ. 2015. Preliminary investigations of bisphenol $\mathrm{A}$ in sediment and suspended matter in Kaštela Bay (Adriatic Sea, Croatia). Acta Adriat., 56(2): 259-268.

ARIAS, A.H., A. VASQUEZ- BOTELLO, N. TOMBESI, G. PONCE-VALEZ, H. FREIJE \& J. MARCOVECCHIO. 2010. Presence, distribution, and origins of polycyclic aromatic hydrocarbons (PAHs) in sediments from Bahia Blanca estuary, Argentina. Environ. Monit. Assess., 160: 301-314.

ARTEGIANI, D., E. BREGANT, N. PASCHINI, N. PINARDI, F. RAICICH, \& A. RUSSO. 1997. The Adriatic Sea general circulation. Part I: Airsea interactions and water mass structure. J. Phys. Oceanogr., 27: 1492-1514.

ATSDR. 1990b. Toxicological Profile for Polycyclic Aromatic Hydrocarbons. ATSDR/ TP-90/20.

BAUMARD, P., H. BUDZINSKI \& P. GARRIGUES. 1998B. PAHs in Arcachon bay, France. Origin and biomonitoring with caged organisms. Mar. Pollut. Bull., 36: 577-586.

BEHYMER, T.D. \& R.A. HITES. 1985. Photolysis of polycyclic aromatic hydrocarbons adsorbed on simulated atmospheric particulates. Environ. Sci. Technol., 19: 1004-1006.

BENTLAHCEN, K.T., A. CHAOUI, H. BUDZINSKI, J. BELLOCQO \& P.H. GARRIGUES. 1997. Distribution and suorces of polycyclic aromatic hydrocarbons in some Mediterranean coastal sediments. Mar. Pollut. Bull., 34: 298305.

BOGNER D. \& A. MATIJEVIĆ. 2016. Variety of physical-chemical characteristics of Holocene sediment from the middle Adriatic Sea (Croatia). Acta Adriat., 57(1): 3-16.

BUCHELI, T.D., F. BLUM, A. DESAULES \& O. GUSTAFSSON. 2004. Polycyclic aromatic hydrocarbons, black carbon, and molecular markers in soils of Switzerland. Chemosphere, 56: 1061- 1076.
BUDZINSKI, H., I. JONES, J. BELLOCQ, C. PIERARD \& P. GARRIGUES. 1997. Evaluation of sediment contamination by polycyclic aromatic hydrocarbons in the Gironde estuary. Mar. Chem., 58: 85-97.

CASAGRANDE, A. 1948. Classification and identification of soils. Am. Soc. Civil Engineers Trans., 113: 901-930.

DE LUCA, G., A. FURESI, R. LEARDI, G. MICERA, A. PANZANELLI, P.C. PIU \& G. SANNA. 2004. Polycyclic aromatic hydrocarbons assessment in the sediments of the Porto Tores Harbor (Northern Sardinia, Italy). Mar. Chem., 86: 15-32.

DUJMOV, J., P. SUČEVIĆ \& M. TONKOVIĆ. 1994. Ratio between PAH content in fish-striped mullet and sediments in the Eastern Adriatic Sea. Toxicol. Environ. Chem., 46: 73-80.

EHRENHAUSER, F.S. 2015. PAH and IUPAC Nomenclature. Polycyclic Aromatic Compounds, 3: 161-176.

ELMQUIST M, Z. ZENCAK \& O. GUSTAFSSON. 2007. A 700 year sediment record of black carbon and Polycyclic Aromatic Hydrocarbons near the EMEP Air Monitoring Station in Aspvreten, Sweden. Environ. Sci. Technol., 41:6926-6932.

FATTORE, E., E. BENFENATI, G. MARIANI, E. COOLS, G. VEZZOLI \& R. FANELLI. 1997. Analysis of organic micropollutants in sediment samples of the Venice Lagoon, Italy. Water. Air. Soil. Pollut., 99: 237-244.

FOLK, R. L. 1954. The distinction between grain size and mineral composition in sedimentary rocks. J. Geol., 62: 344-356.

GOGOU, A., I. BOULOUBASSI \& E.G. STEPHANOU. 2000. Marine organic geochemistry of the Eastern Mediterranean: 1. Aliphatic and polyaromatic hydrocarbons in Cretan Sea surficial sediments. Mar. Chem., 68: 265-282.

GSCHWEND, P.M. \& R.A. HITES. 1981. Fluxes of polycyclic aromatic hydrocarbons to marine and lacustrine sediments in the northeastern United States. Geochim. Cosmochim. Acta, 45: 2359-2367.

GRILLI, F., M. MARINI, J.W. BOOK, A. CAMPANELLI, E. PASCHINI \& A. RUSSO. 2013. Flux of 
nutrients between the middle and southern Adriatic Sea (Gargano-Split section). Mar. Chem., 153:1-14.

GRIMMER, G., J. JACOB, K-W. NAUJACK \& G. DETTBARN. 1983. Determination of polycyclic aromatic compounds emitted from browncoal-fired residential stoves by gas chromatography/mass spectrometry. Anal. Chem., 55:892 - 900 .

GUO, J., N.L. WANG, S. KITANAKA \& X.S. YAO. 2007. 9,10-Dihydrophenanthrene derivatives from Pholidota yunnanensis and scavenging activity on DPPH free radical. J. Asian Nat. Prod. Res., 9:165 - 174.

GUZZELLA, L. \& A. DE PAOLIS. 1994. Polycyclic aromatic hydrocarbons in sediments of the Adriatic Sea. Mar. Pollut. Bull., 28 (3): 159-164.

HEATH, E., N. OGRINC, J. FAGANELI \& S. COVELLI. 2006. Sedimentary record of polycyclic aromatic hydrocarbons in the Gulf of Trieste (Northern Adriatic Sea). Water Air Soil Pollut., Focus 6 (5-6): 605-614.

IQBAL, J., E.B. OVERTON \& D. GISCLAIR. 2008. Sources of polyaromatic hydrocarbons in Luisiana River and coastal environments: Principal component analyses. Environ. Forensics, 9: 310-319.

KIM, M., M.C. KENNICUTT II \& Q. YAORONG. 2008.

Source characterization using compound composition and stable carbon isotope ratio of PAHs in sediments from lakes, harbor and shipping waterway. Sci. Total. Environ., 389:367-377.

LEHNDORFF E. \& L. SCHWARK. 2009. Biomonitoring airborne parent and alkylated three-ring PAHs in the Greater Cologne Conurbation I: temporal accumulation patterns. Environ. Pollut., 157:1323-1331.

LIMA, A.L., J.W. FARRINGTON \& C.M. REDDY. 2005. Combustion-derived polycyclic aromatic hydrocarbons in the environment - a review. Environ. Forensics, 6: 109-131.

LUO, X.J., S.J. CHEN, B.X. MAI, G.Y. SHENG, J.M. FU \& E.Y. ZENG. 2008. Distribution, source apportionment, and transport of PAHs in sediments from the Pearl River delta and the northern South China Sea. Arch. Environ. Contam. Toxicol. 55:11-20.
LUNDSTEDT, S., P.A. WHITE, C.L. LEMIEUX, K.D. LYNES, I.B. LAMBERT, L. ÖBERG, P. HAGLUND $\&$ M. TYSKLIND. 2007. Sources, fate, and toxic hazards of oxygenated polycyclic aromatic hydrocarbons (PAHs) at PAH-contaminated sites. Ambio: J. Human. Environ., 36(6): 475-485.

MAGI, E., R.BIANCO, C. IANNI \& M. DI CARRO. 2002. Distribution of polycyclic aromatic hydrocarbons in the sediments of the Adriatic Sea. Environ. Pollut., 119: 91-98.

MARINI, M. \& E. FRAPACINI 2013. Persistence of polycyclic aromatic hydrocarbons in sediments in the deeper area of the Northern Adriatic Sea (Mediterranean Sea). Chemosphere, 90:1839-1846.

MARINI, M., V. MASELLI, A. CAMPANELLI, F. FOGLINI \& F. GRILLI. 2015. Role of the Mid-Adriatic deep in dense water interception and modification. Mar. Geol., 375 : 5-14. DOI: http://dx.doi.org/10.1016/j.margeo.2015.08.015

MEANS, J.C. 1995. Influence of salinity upon sediment-water partitioning of aromatic hydrocarbons. Mar. Chem. 51: 3-16.

NEFF, J.M., 1979. Polycyclic aromatic hydrocarbons in the aquatic environment, sources, fates and biological effect. Applied Science Publishers Ltd. Essex, England.

NOTAR, M., H. LESKOVS \& J. FAGANELI. 2001. Composition, distribution and sources of polycyclic aromatic hydrocarbons in sediments of the gulf of Trieste, Northern Adriatic Sea. Mar. Pollut. Bull., 42: 36-44.

NRCC. 1983. Polycyclic aromatic hydrocarbons in the aquatic environment: Formation, sources, fate and effects on aquatic biota. Publication No. NRCC 18981. NRC Associate Committee on Scientific Criteria for Environmental Quality, Ottawa, ONTARIO, $209 \mathrm{p}$.

PAYNE, J. F. J., L.L. KICENIUK, U. FANCEY, G.L. WILLIAMS, A. FLETCHER, A. RAHIMTULA \& B. FOWLER. 1993. What Is a Safe Level of Polycyclic Aromatic Hydrocarbons for Fish: Subchronic Toxicity Study on Winter Flounder (Pseudopleuronectes americanus). Can. J. Fish. Aquat. Sci., 45: 1983-1993. 
RAVAIOLI, M., F. ALVISI, \& L. MENEGAZZO-VITTURI. 2003. Dolomite as a tracer for sediment transport and deposition on the northwestern Adriatic continental shelf (Adriatic Sea, Italy). Cont. Shelf Res. 23, 1359-1377.

SANTODONATO, J., P. HOWARD \& D. BASU. 1981. Health and Ecological Assessment of Polynuclear Aromatic Hydrocarbons. J. Environ. Pathol. Toxicol., 5: 1-364.

SICRE, M.A., J.C. MARTY, A. SALIOT, X. APARICIO, J. GRIMALT \& J. ALBAIGES. 1987. Aliphatic and aromatic hydrocarbons in different sized aerosols over the Mediterranean Sea: occurrence and origin. Atmos. Environ., 21: 22472259.

SOCLO, H.H., P.H. GARRIGUES \& M. EWALD. 2000. Origin of polycyclic aromatic hydrocarbons (PAHs) in coastal and marine sediments: Case studies in Cotonou (Benin) and Aquitane (France) Areas. Mar. Pollut. Bull., 40(5): 387-396.

STOUT, S.A., A.D. UHLER \& S.D. EMSBO-MATTINGLY. 2004. Comparative evaluation of background anthropogenic hydrocarbons in surficial sediments from Nine urban waterways. Environ. Sci. Technol., 38: 29872994.

TOLOSA, I., S. DE MORA, M.R. SHEIKHOLESLAMI, J.P. VILLENEUVE, J. BARTOCCI \& C. CATTINI. 2004. Aliphatic and aromatic hydrocarbons in coastal Caspian Sea sediments. Mar. Pollut. Bull., 48: 44-60.

TOBISZEWSKI, M., \& J. NAMIESNIK. 2012. PAH diagnostic ratios for identification of pollution emission sources. Environ. Pollut., 162: 110-119.

TRONCZYNSKI, J., C.MUNCSHY, K. HEAS-MOISAN, N. GUIOT, I. TRUQUET, N. OLIVIER, S. MEN \& A. FURAUT. 2004. Contamination of the Bay of Biscay by polycyclic aromatic hydrocarbons (PAHs) following the T/V "Erika" oil spill. Aquat. Living. Resour., 17: 243-259.

TSAPAKIS, M., E.G. STEPHANOU \& I. KARAKASSIS. 2003. Evaluation of atmospheric transport as a nonpoint source of polycyclic aromatic hydrocarbons in marine sediments of the Eastern Mediterranean. Mar. Chem., 80: 283-298.

USEPA. 1980. Ambient water quality criteria for polynuclear aromatic hydrocarbons. EPA 440/5-80-069. US NTIS PB81-117806. USEPA, Washington, DC.

VILIBIĆ, I. \& M. ORLIĆ. 2002. Adriatic water masses, their rates of formation and transport through the Otranto Strait. Deep Sea Res., 49:1321-1340.

VOLLHARDT, K.P.C., \& N.E. SCHORE. 1999. Organic Chemistry, 3rd edit., W. H. Freeman and Company, New York.

WAKEHAM, S. G. 1996. Aliphatic and polycyclic aromatic hydrocarbons in Black Sea sediments. Mar. Chem., 53: 187-205.

WANG, S., N. NATH, G. FUSARO \& S. CHELLAPPAN 1999b. Rb and prohibitin target distinct regions of $\mathrm{E} 2 \mathrm{~F} 1$ for repression and respond to different upstream signals. Mol. Cell. Biol., 19:7447-7460.

WENTHWORTH, C.K. 1922. A scale of grade and class term for class term for clastic sediments. J. Geology, 30: 377-392.

YAN, B., T.A. ABRAJANO, R.F. BOPP, L.A. BENEDICT, D.A. CHAKY, E. PERRY, J. SONG \& D.P. KEANE. 2006. Combined application of $\delta 13 \mathrm{C}$ and molecular ratios in sediment cores for $\mathrm{PAH}$ source apportionment in the New York/New Jersey harbor complex. Org. Geochem., 37:674-687.

YAN, B., R.F. BOPP, D.A. CHAKY, S.N. CHILLRUD, \& T.A. ABRAJANO. 2007. Organic contaminant sources to the lower Hudson basin. Environmental monitoring and protection in New York: linking science and policy, Poster Abstracts, NYSERDA, 15-16 November, New York, NY, USA.

YUNKER, M., R. MACDONALD, R. VINGARZAN, R. MITCHELL, D. GOYETTE \& S. SYLVESTRE. 2002. PAHs in the Fraser Rive Basin: A critical appraisal of PAH ratios as indicators of PAH source and composition. Org. Geochem., 33: 489-515. 


\title{
Koncentracije i porijeklo policikličkih aromatskih ugljikovodika u sedimentima srednjeg Jadrana
}

\author{
Jelena MANDIĆ* i Maja PAVELA VRANČIĆ
}

"Kontakte-adresa: mandic@izor.hr

\begin{abstract}
SAŽETAK
Policiklički aromatski spojevi (PAC) i njihovi supstituirani homolozi su istraživani u sedimentu na osam postaja smještenih uzduž transekta Hrvatska-Italija, u srednjem Jadranu. U svakom uzorku određeno je ukupno 208 spojeva. PAC koncentracije, izmjerene u sedimentima u priobalnom području, bile su više od PAC koncentracija izmjerenih u sedimentima otvorenog mora. Najviša koncentracija izmjerena je u području teretne luke Split. Policiklički aromatski ugljikovodici (PAH) bili su dominantna grupa spojeva u svim istraživanim uzorcima s udjelima u ukupnoj koncentraciji PAC-ova višim od 85\%. Maseni udjeli S-PAH-ova bili su viši od masenih udjela O-PAH-ova u svim uzorcima te su opadali udaljavanjem od obale. Doprinos O-PAH u ukupnom masenom udjelu PACova povećavao se udaljavanjem od obale dok su doprinosi S-PAH bili viši u priobalnom području što upućuje na njihovo različito porijeklo. Granulometrijskom analizom sedimenta utvrđeno je da su sedimenti u priobalnom području sadržavali povišeni udio finih, muljevitih čestica dok su čestice veličine pijeska bile dominantna frakcija u sedimentima otvorenog mora. Udjeli ukupnog organskog ugljika (TOC) bili su niži u sedimentima uz obalu gdje su izmjereni povišeni maseni udjeli PAC-ova što upućuje na njihovo različito porijeklo. Izvori PAH-ova istraženi su primjenom dijagnostičkih omjera. Pirogeno porijeklo PAH-ova određeno je na samo jednoj postaji, smještenoj u priobalju, dok su na postajama otvorenog mora dominirali PAH-ovi iz petrogenih izvora. Rezultati upućuju da je pomorski promet glavni izvor onečišćenja u području otvorenog mora.
\end{abstract}

Ključne riječi: policiklički aromatski spojevi, PAH-ovi, sediment, porijeklo PAH-ova dijagnostički omjeri, onečišćenje mora, Jadransko more 